


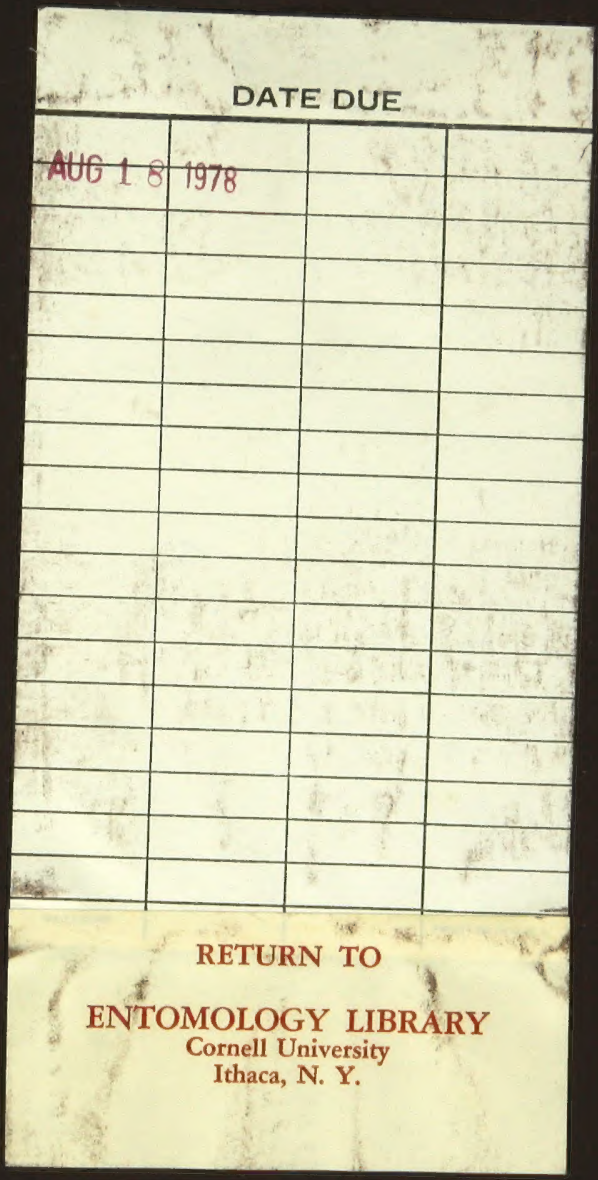




$$
\begin{aligned}
& 9605 C 651 \\
& \text { ENT } \\
& \text { RARE } \\
& \text { QL561 } \\
& \text { P9L4 }
\end{aligned}
$$

$44^{\circ}$ 


\title{
BRITISH PYRALIDES,
}

INCLUDING THE

\section{PTEROPH OR I D E.}

\author{
BY \\ JOHN HENRY LEECH, B.A., \\ F.L.8., F.Z.8., ETc.
}

LONDON:

R. H. PORTER, 6 TENTERDEN STREET, W. 1886. 
ENT

RARE

QL561

PqL4

\section{$9605 C 65$.}

A. 33410

CORNELL

UVYVERSITY

LIBRARY

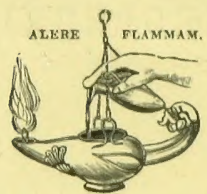

TRINTED BY TAYLOR AND FRANCIS, RED LION COUIT, FLEET STHEET. 


\section{INTRODUCTION.}

WhiLst the history of Tortrices has been so ably treated by Mr. Wilkinson and the Tineina by Mr. Stainton, the Pyralidæ and their allies have been so far somewhat neglected in this country. The object of this treatise is to set before the student an illustrated list of the British examples of this group; and, as far as the writer's knowledge and research will carry him, the localities and conditions in which each species has been found, the dates of their appearance, and also a brief description of their larvæ and food-plants.

The life-history of these species is in many cases founded on the personal experience of the writer, or 
else compiled from the numerous books and magazines referring to the subject by German and French as well as English authors. References will be given in each case where a fuller description may be found in English periodicals.

The study of local fauna, even of such a puny character as that with which the present work deals, cannot be without interest even to the most casual observer; whilst the elimination of error, in the sifting away of doubtful information, no matter how feeble the attempt may be, must always be welcomed and encouraged by every scientific enthusiast.

In conclusion I beg to offer my best thanks to

$$
\begin{aligned}
& \text { Mr. C. G. Barrett, } \\
& \text { Mr. Briggs, } \\
& \text { Rev. Bloomfield, } \\
& \text { Dr. Buchanan White, } \\
& \text { Mr. W. H. Harwood, } \\
& \text { Mr. E. G. Meek, } \\
& \text { Mr. Richard South, } \\
& \text { Mr. Howard VaUghan, } \\
& \text { Mr. F. O. Walker, }
\end{aligned}
$$


for the most valuable assistance and information they have been kind enough to place at my disposal.

Of course it is impossible that a work of this description can be entirely free from errors; but if it should stimulate collectors to fresh researches in the distribution and habits of this branch of entomology, its end and object would be more than gained. 



\section{NOTE.}

Tre methods used for collecting Lepidoptera have been so often and so exhaustively deseribed that it is unnecessary to refer to them. Suffice it to say, that the author has always found it best to box every specimen alive, and kill them on his return by placing all the boxes with their contents in a large air-tight tin canister, containing either erushed laurel-leaves or pure ammonia on a piece of sponge. They will be found in excellent condition for setting on the following morning.

The Continental method of setting (i.e. with the wings flat, and the pin driven three-quarters of the way through the inseet, perpendicular to the plane of the wings) will be found far preferable to the mode of setting prevalent in this country (in which the pins are found to be usually placed at varying angles and the wings at different slopes).

The advantages of the former method are:-

(1) The shape of the wings is casicr to see;

(2) The fringes do not get damaged against the bottom of the drawer; 
(3) The specimens are safer from mites, dust, \&c.;

(1) There is room under each specimen for a ticket, recording locality and date of capture, which should never be omitted.

It is quite unnecessary to use the continental pins, as the finer ones are inconveniently flexible, and they are too long for English cabinet drawers.

This method is being adopted at the British Muscum of Natural Ifistory and by many of the leading English entomologists. The enormous advantages of this method of setting over any other are so obvious that its general adoption in this country is only a matter of time.

** Setting-boards can be obtained at a very reasonable price from Mr. Crockett. 


\section{BRITISH PYRALIDES, ETC.}

\section{AVENTIIDE.}

\section{Aventia flexula, Schiff.}

sinuata, $\mathrm{Fb}$.

(Plate 2. fig. 3.)

Loc. Rugby, Almondsbury, Bath, Scarborough, York, Norwich, Chedgrave, Merton, Neatishead, IIorning, Bournemouth.

Frequents fir-woods in July.

This larva possesses only two pairs of abdominal legs. According to Dr. O. Ifofmanu it feeds from the autumn till June on licheus growing on fir trees. It is green, with black markings; head grey. The author's figure, however, is a purple larva with white markings. Pupates in a slight cocoon.

\section{HERMINIIDA.}

Rivula sericealis, Scop.

(Plate 1. fig. 9.)

Loc. Lochgoil, Arran, Exxeter, Bristol, Ledsham, 
York, Norwich, Brooke, Surlingham, Aldeby, Merton, Barton, Epping, Colchester, St. Osyth, Deal, Southend, Galway, Pembroke.

This species frequents woods during June and July. The larva, which feeds on Brachypodium sylvaticum and other grasses, is velvety green, with a darker dorsal and white subdorsal lines; head dull green, with dark hairs and markings; tubercles shining green, with a black apex and liair; spiracles flesh-colour, ringed with black; legs green. It passes the winter in the larval state, pupating about the end of the following May in a blade of grass folded together by means of silk threads.

E. M. M. xix. 49.

\section{Zanclognatha grisealis, $H b$.} nemoralis, $\mathrm{Fb}$.

\section{(Plate 2. fig. 1.)}

Loc. S.W. of Scotland, Devonshire, Eastham, Wirral, Chester, IIuddersficld, Riclmond (York.), Shefficld, Norwich, Aldeby, Merton, Colchester, Hastings, Suffolk, Southend, Pembroke, Kingstown.

Common in woods during June and July.

'The larva, which feeds on oak, is pinkish grey, slightly freckled with darker; the head and dorsal plate dark brown ; dorsal and subdorsal lines, spiracles, and tubercles all of a darker shade of the groundcolour; ablominal surface paler. This larva pupates in September between leaves spun together.

T. M. M. xiii. 110.

Ent. iii. 223. 
Zanclognatha tarsipennalis, $T$ r.

tarsicrinalis, Hb., Haw.

(Plate 1. fig. 12.)

Loc. S. W. of Scotland, Ayrshire, Bristol, Burton, Molywell, Bramham, IIuddersficld, Scarborough, Shefficld, York, Norwich, Aldeby, Thetford, Lymm, Colchester, IIastings, Suffolk, Southend, Conway, Chatham, Ipping, Pembroke, Galway.

Common from May to July and again in September in woods.

The larva, which feeds on Polygonum aviculare (knotgrass) \&c., is dull brownish grey, freckled with a darker tint; the head, plate on the sccond segment, dorsal and subdorsal lines, and spiracles are darker than the ground-colour. It pupates in a slight cocoon amongst leaves \&c.

E. M. M. x. 101 .

\section{Zanclognatha emortualis, Schiff. olivaria, Bork.}

(Plate 1. fig. 8.)

Loc. Epping, IIenley-on-Thames, Dorsetshire.

Rare from the end of May to July in woods.

The larva, which fecds on oak, preferring the dead leaves, is brownish yellow, spotted with orange-brown; dorsal line brown; on the back of each segment are four black dots arranged quadrangularly, bclow which occur on each side two black spots, from each of which springs a single black hair; head thick and round. The 
larva pupates in a white silk cocoon amongst leaves in October.

Treit.

\section{Herminia cribralis, $H b$.}

(Plate 2. fig. 2.)

Loc. Glastonbury, Diss, Merton, Ranworth, Horning, Aldcby, Walton-on-the-Nazc, Suffolk, Wicken, Southend.

This species, which occurs in fens and marsliy fields, is found in July.

The larva, which fecds on sallow (Carex sylvatica) and Luzula pilosa (wood liairy rush), is a light greyish brown, freckled with ochrcous; dorsal line darker than the ground-colour, edged with paler; subdorsal line palc; spiracles black; belly pale. It hybernates, and the following spring it spins a slight cocoon amongst its food, \&c.

E. M. M. x. 103 .

Herminia derivalis, $H b$.

emortualis, Haw.

(Plate 1. fig. 10.)

Loc. Woolwich, Deal, Lewes, Colchester, IIastings, Herne Bay.

In July and August in damp woods, very local.

The larva fects on decaying oak-leaves; it is dark velvety brown, pubescent; dorsal and sublorsal lines slightly darker than the ground-colour; spiracles ringed with black; the plate on the second segment is divided by a paler line of the ground-colour; abdominal surface 
somewhat paler. This larva hybernates, and pupates the following June or July between leaves spun together.

E. M. M. x. 102 .

Pechypogon barbalis, Clerck. pectitalis, Illb.

(Plate 1. fig. 11.)

Loc. Devoushire, Weston-super-Mare, Wakefich, York, Foulsham, Cawston, Horning, Colchester, IIastings, Suffolk, Southend, Ireland.

This species is generally common in roods from June to August.

The laxva, which feeds on birch-catkins, also on oak, is deep reddish ochreous ; there is a pattern of diamond markings on the back and sides; the dorsal line is blackish; spiracles black; segmental divisions pale ochreous; head dusky; skin soft and velvety. It lybernates, and at the end of the following April spins itself a cocoon amongst leaves, débris, \&e.

E. M. M. x. 100 .

\section{HYPENIDE.}

Madopa salicalis, Schiff.

obliquata, Fb.

(Plate 1. fig. 1.)

Loc. West Wicklam, Kent.

Occurs in May and Junc; not common, amongst low brushwood \&c. ; comes to light.

'The larva is velvety green, with yellow segmental inci- 
sions ; head and abdominal surface paler ; possesses only three pairs of abdominal legs; spixacles black. It feeds on sallow and willow in July and August; forms a cocoon of silk covered with débris.

Treit., Guen., \&e.

Bomolocha fontis, $T h n b$.

crassalis, $\mathbf{F b}$.

(Plate 1. fig. 4.)

Loc. Plymouth, Spitchwick, Dunsforl, Clovelly, Hastings, Suffolk, IIaslemere, Dorking, Staffordshire, Sevenoaks, South of Ireland, Leith Hill, Carrick-onShannon.

Occurs from the middle of June to the middle of July, usually amongst bilberry.

Var. terricularis, $H b$. In this varicty the wings are nearly black, with white markings.

The larva is green, with three dark lines; spiracles black; pale spots on the segments. On heath (?), bilberry, nettle (?). It forms a cocoon among leaves in the autumn. Treit., Hofmann, \&c.

Hypena rostralis, $L$.

(Plate 1. fig. 3.)

Loc. Plymouth, Almondsbury, Shefficld, Lymn, Norwich, Thetford, Colchester, Hastings, Suffolk, Bromley, Kent, Ireland.

In June, July, and again in September. Iybernated specimens occur also in April. 
Var. radiatus is redder, with dark veins.

The larva, which fecis in May and June and again in August and September on hops (Itumulus lupulus) and nettle, is green, with a darker dorsal line and white lateral stripes; head brownish yellow ; tubercles black ; the first pair of abdominal feet wanting. It pupates amongst leaves.

\section{Hypena obsitalis, $H b$.}

(Plate 13. fig. 7.)

Loc. Bloxworth (Dorset).

Occurs in June and again in Scptember, many of the later brood hybernating. Common in sheltered places all over Southern Europe, Northern Afrien, Madeira, Canaries, \&c.; very variable, but always distinct from any other species.

The larva is bright yellowish green, with a dark dorsal and pale subdorsal lines; feeds in May on Parietaria (pellitory).

\section{Hypena proboscidalis, $L$.}

(Plate 1. fig. 2.)

Loc. Scotland (abundant), Rugby, Marlborough, Plymouth, Bristol, Chester, Yorkshire, Lynn, Colchester, II astings, Suffolk, Ireland, Pembroke, Carmarthen.

In June and July, sometimes again in autumn; common on weedy banks.

The larva, which feeds in May and June on nettles (Urtica wrens), is bright grecn, with yellowish segmental 
incisions; dorsal line darker, sublorsal lines yellowish; abdominal surface paler than back; head and legs green; tubercles pale, each bearing a brown hair. The larva forms a cocoon amongst leaves.

\section{Hypenodes albistrigalis, Haw. (Plate 1. fig. 5.)}

Loc. Plymouth, Exmouth, Barnstaple, Dartmonth, Frome, Scarborough, Aldeby, Merton, Guestling, Suffolk, Deal, Pembroke, Canterbury, Linton, 'Tilgate Forest, Monkswood (Huntingdon).

This species occurs in woods in Junc and July, and comes freely to sugar.

Hypenodes costæstrigalis, St.

acuminalis, WV.

(Plate 1. fig. 6.)

Loc. Lochgoil IIcad, Barnstaple, Dartmouth, North Devon, Bristol, Bidston, Chester, Askham Bog, IIarrowgate, Searborough, Shefficld, York, Merton, Cawston, IIorning, IIastings, Suflolk, Boumcmouth, Canterbury, Epping, New lorest.

Frequents woods in July, comes also to sugar like the preceding species.

'The larva, which feeds on Thymus serpyllum, is dark purplish or crimson brown, shing; dorsal and subdorsal lines slightly paler; sides and ventral surface also paler. This larva possesses only two pairs of ventral legs, or twelve in all. It forms a cocoon in which it pupates.

E. M. M. vi, 216. 


\section{Tholomiges turfosalis, $W k$.}

hrmidalis, Dbl.

(Plate 1. fig. 7.)

Loc. Rannoch, Killarney, Keswick, Crewe, New Forest, Norfolk, Chat Moss (Lancashire).

This species flies during the early part of the evening in damp situations on heaths, in July.

\section{PYRALIDIDE.}

Cledeobia angustalis, Schiff.

bombycatus, IIaw.

(Plate 2. fig. 10.)

Loc. Plymoutl, Minchead, Maltlyy Woods (York.), Walton-on-the-Naze, Colchester, Teuby, Ilastiugs, Suffolk, Southend, Deal, Pembroke.

Occurs in June and July in dry sandy localitics.

The larva, which feeds in gallerics among noss (Hypnum cupressiforme), is smoky black; rentral surface paler; head black, glossy; frontal plate chocolatecolour, glossy ; anal segment pale brown ; medio-dorsal line black. It forms a cocoon among moss.

$A$ variety of the larva occurs in which the groundcolour is light chocolate, suffused with smoke-colour.

E. M. M. xxi. 12t.

Aglossa pinguinalis, $L$.

(Plate 2. fig. 8.)

Loc. Scotland (widely distributed), Rugby, Plymouth, 
Bristol, Chester, Bradford, Bramham, IIuddersfield, Leeds, Sheffield, Wakefield, York, Norfolk, Colchester, IIastings, Suflolk, Outer Ifebrides, Arran, Pembroke, Ireland.

Oceurs cverywhere, in stables, outhouses, \&c., in June and July. A very variable species.

Var. Streatfieldii, Curt. Fore wings uniform grey, with a dark basal and terminal band and a black cellular spot.

The larva is black or dark brown; legs drab; belly bronzy. It lives in a silken gallery covered with particles of débris amongst its foot, viz. the refuse of barn-floors, \&c. It hybernates, never leaving its gallery until full-fed, when it seeks a convenient situation in which to spin its cocoon, which is externally covered with bits of its surroundings, mortar, rubbish, \&c. It has a great aversion to grease. $\quad$ E. M. M. xx. 193.

Aglossa cuprealis, $H b$.

capreolatus, Haw.

(Plate 2. fig. 9.)

Loc. Stapleton?, Huddersfield?, Colchester, Suffolk, Cambridge, Southend.

This species also occupies outhouses \&c. in June and July. The larva lives in the same manner as pinguinulis, in galleries, under the refuse of bam-floors, and similar localities, feeding on chaff, bits of dried grass, straw, \&c. It hybernates.

The larva is brilliant bronze; hind segments rather paler; head deep chestnut-red ; collar decper red, cdged 
in front with black; anal plate reddish. It spins a white silken cocoon covered externally with particles of straw and liusks, amongst which it lives.

E. M. M. xxi. 75 .

Pyralis costalis, $F b$.

fimbrialis, Schiff.

(Plate 2. fig. 5.)

Loc. Bristol, York, Merton, Cawston, IIorning, Colchester, IIastings, Suffolk, Southend, Chingford, London.

In July and August.

The larva is dull olive-brown; along cach side occur two series of polished light spaces, the upper row with a dark shining central spot emitting a lair, the lower row of squarer spaces are more tumid and have two black spots, one, smaller, below the other; venter paler than dorsum, with a row of dots bearing a fine hair on each side; legs the same colour as venter, the abdominals with a spot and hair exteriorly. This larva is very variable in colour. It feeds on stacked clover, preferring the lower and moister parts, living in a web. 'There are several broods during the year. In some States of America it is very injurious to crops.

Riley's Sixth $\Lambda$ nnual Report on the Injurious Insects of Missouri, 1874 . 
Pyralis glancinalis, $L$.

nitidalis, Fb., IIb.

(Plate 2. fig. 7.)

Loc. Marlborough, Stapleton, Clifton, $\Lambda$ skham Bog, Scarborough, Wakefield, Norfolk, Colchester, II astings, Suffolk, Southend, Deal, Bromley, Wicklow, Carrington Moss.

In Junc, July, and August.

The larva feeds in the "nest-like bunches of twigg" which grow on birch trees, also old thatch and the pith of old raspberry-canes. The ground-colour is dark bronzy green, becoming paler along the spiracles, belly, and legs; the head and the second and thirteenth segments are also paler; a fine black undulating line runs along under the spiracles, which are inconspicuous. It lives in a gallery, and spins a silken cocoon in April. E. M. M. vi. 111.

\section{Pyralis farinalis, $L$. \\ (Plate 2. fig. 6.)}

Loc. Scotland (as far north as Aberdecn), Plymouth, Deronshire, Bristol, New Ferry, Bradford, Bramham, Ifuddersfield, Leeds, Wakeficld, York, Norfolk, Colchester, IIastings, Suffolk, Bromley, Pembroke, Ireland.

Common everywhere from June to October about houses.

The larva is bone-white, becoming whiter towards the ventral surface; head shining chestnut-brown; mouth blackish; sceond segment pale brown; anal plate yellowish brown; there is a blackish tinge over the 
anterior and posterior segments (distinguishing character of the species); spiracles ringed with black; legs tipped with brown hooks. This larva lives through two winters; it inliabits long tubes of silk mixed with flour, \&c., in sechuded situations about flour-mills, under corn-bins, \&c. It fecds, like Aglossa pinguinalis, ou mixed rubbish, and forms a cocoon of white silk covered with rubbish.

E. M. M. xxi. 248 .

\section{Pyxalis lienigialis, Zell.}

(Plate 7. fig. 1.)

This species has been taken at light during $\Lambda$ ugust and September near Stony Stratford by Mr. W. Thompson and other collectors. It is extremely rare in collections, being only otherwise recorded from Finland and Livonia,

Scoparia cembræ, Haw.

cembralis, $\mathrm{Gn}$.

(Plate 14. fig. 1.)

Loc. Scotland (widely distributed), Radford, Devonshire, Bristol, Denhall, Bradford, Bramham, Redear, Scarborough, Shefficld, Norwich, Aldeby, Iunstanton, Wootton, Colchester, IIastings, Suffolk, Tcignmouth, Pembroke, Howth, Southend, Deal.

This species oecurs on fir-trunks, but also in ficlds.

Var. Zelleri, Wh. (Plate 14. fig. 2), is rather larger than the type, and has the markings more distinct; it usually occurs in the same localities. 
Loc. Paisley, North Devon, Bristol, Huddersfield, Carmarthen, Norwood, Teignmouth, Wolverton.

Var. scotica, White, E. M. M. viii. 169 (Plate 14. fig. 3). The fore wings are grey with the markings more distinct than in the type, the hind wings silky white; the fore wings are more triangular and broader.

Loc. Near Perth. Has been taken in company with the type.

\section{Scoparia basistrigalis, Knaggs.}

(Plate 14. fig. 4.)

Loc. Plymouth, Portbury, Edlington Wood, Doncaster, Selby, York, Norwich, Aldeby, Suffolk, Sussex, Worcestershire, Haslemere, Tilgate Forest.

This species cannot be confounded with any other except ambigualis, from which the greater width of the fore wings, its deeper markings, and larger size at once scparate it, not to mention its entirely different shape.

A dark form of the female occurs.

Scoparia ambigualis, $7 \%$.

dubita, IIaw.

(Plate 14. fig. 5.)

Loc. Scotland (Lowlands), Rugby, Plymouth, Devonshire, Bristol, Wirral, Chester, Yorkshire, Norwich, Cawston, Lymm, Colchester, Mastiugs, Suffolk, Shetland, Pembroke, Southend, Deal, Folkestone, Powerscourt (near Dublin). 
From Junc to $\Lambda$ ugust, at rest on trees, common nearly everywhere.

'The larva is said to feed on moss and lichen on oak and beech trees.

\section{Scoparia atomalis, $D b l$.}

(Plate 14. fig. 6.)

Loc. Scotland (common on Ilighlands), Duntocher, Bingley, Orkney, Isle of Unst (Shetlands).

Common in the north of England.

It can be casily separated from ambigualis, its nearest ally, by its smaller size, darker markings, straighter costa, and more triangular fore wings.

Scoparia conspicualis, Hodgn.

(Plate 14. fig. 7.)

Loc. Doncaster, Windermere, Sandburn, Upper Wharfedale, Wilsden (York.).

This species occurs in June, July, and $\Lambda$ ugust. It can be recognized from any other species by the pale basal and marginal areas. The female is usually greyer than the male.

Scoparia ulmella, Dale. (Plate 14. fig. 8.)

This speces is distinguished from dubitalis by the slender conformation of the wings; also the characters of the first line, arehed concavely towards the base of 
wing, in which the stigmata are scarcely visible; the very characteristic renal stigma, filled in with ochreous; and the apical markings of the fore wings.

The only three known examples of this species were taken by Mr. Dale, on the 13th of July, 18\%1, on a wych-elm tree, in a thick wood at East Meon.

E. M. M. iii. $21 \%$.

Scoparia dubitalis, $H b$.

pyralella, IIb.

(Plate 14. fig. 9.)

Loc. Scotland (widely distributed), Plymouth, Devonshire, Bristol, Ledsham, Puddington, Bramham, IIarrowgate, IIuddersficld, Richmond (York.), Norwich, Roydon, Colchester, Pembroke, II astings, Ireland, Southend.

Common in June and July in damp situations. Easily distinguished from other Scoparice by the shape of the stigmata, filled-in with buff.

Var. ingratella, Zell. (Plate 1 l. fig. 10), is a larger and paler insect, with fewer markings. It has a habit of resting on lumps of chalk.

It occurs at Folkestone, Plymouth, Brandon, Pcmbroke.

The larva fceds on moss and lichens on oak and becch trees in March and April.

Hartm.

Scoparia truncicolella, Sta.

mercuriellus, Zinck., Tr.

(Plate 14. fig. 11.)

Loc. Perthshire, Inverness-shirc, Glasgow, I'ly- 
mouth, Excter, Bristol, Wirral, Grassington, Croydon, Leatherhead, Brandon, IIuddersfield, Scarborough, Sheflicld, Norwich, Horsford, Cawston, Mayo.

This common species occurs in July and August. It is at once distinguished from murana by its smaller size, paler and more olive colouring, and the absenee of black markings.

The larva feeds in common moss, which usually grows among short grass. It lives in silken galleries through the winter, and pupates in moss the following spring. Ground-colour dark olive-brown; head dark brown, dorsal line darker; legs and tubercles black.

E. M. M. xviii. 106.

\section{Scoparia murana, Curt. muralis, Gn.}

(Plate 15. fig. 1.)

Loc. Scotland (widely distributed), Carder, Milngavic, Iangside, luxeter, Wirral, Bradford, IIuddersfield, Richmond, Sheffield, Outer IIebrides, Belfast.

This species is common nearly ererywhere in June and July, and again in August. The markings on the fore wings are far darker than in any other Scoparia.

'The larva is generally to be found under moss on old walls, rocks, and stoncs in $A$ pril. It feeds on $73 r y u m$ capillare and Hypnum cupressiforme, in silken galleries. The ground-colour of the larva is brown, tinged with ochre, grey, or purple, becoming paler towards the ventral surface; dorsal line dark brown, also tubereles and dorsal plate; head and plates shining, the anal plate paler brown. It pupates about the end of May.

Ent. xv. 133. 
Scoparia resinea, Haw.

resinalis, $\mathrm{Gn}$.

(Plate 15. fig. 2.)

Loc. Plymonth, Exeter, Bristol, Almondsbury, Lyndlurust, Ventnor, liolkestone, Scarborough, Shefficld, Norwich, Lundy 1sland, Powerscourt, Wicklow.

In July and $\Lambda$ ugust. Can be distinguished by the triangular and pointed fore wings and the dark costal blotch near the apex of the fore wing.

The larva is said to feed on the lichens on ash trees.

Scoparia mercurella, $L$.

frequentella, Str.

(Plate 15. fig. 3.)

Loc. Perthsliire, Sontli-west of Scotland, I'lymouth, Norwich, Devon, Bristol, Ness, Puddington, $\Lambda$ skham 13og, IIudlersficld, Sheflicld, Yarmouth, IIorsford, Colchester, ILastings, Suflulk, P'embroke, Ireland.

Gencrally common at rest on stoncs, walls, sec. It differs from cratayella in its browner aud gencral darker colouring.

Scoparia cratægella, $H b$. crategalis, Gn .

(Plate 15. fig. 4.)

Loc. P'erthshire, Aberdeen, Glasgow, Ayrshirc, Edinlourgh, Plymouth, Cadder, MLilngravie, Bristol, Lyud- 
lurst, 13ingley, Brandon, Bramham, Richmond (York.), Shefficld, Norwich, Cawston, Howth.

Common amongst whitethorn during July and August. It is paler and greyer than the preceding species.

The larva is yellowish green, with large shining tubercles, ench bearing a hair. Ilcad shining dark brown; dorsal plate divided by an indistinct line. Occurs in May under moss on trees, in a tubular silken gallery.

\section{Scoparia phæoleuca, Zell. \\ portlandica, Dale. \\ (Plate 15. fig. 5.)}

Loc. Brandon, Portland.

In July and August. The white basal and marginal bands of the fore wing separate it from every other species.

\section{Scoparia lineolea, Curt.}

lineolalis, Gn.

(Plate 15. fig. 6.)

Loc. Perthshire, Ayrshire, Plymouth, Exeter, Bristol, Doncaster, licilear, Norwich, Galway, Ilowth, l'olkestonc, Isle of Man, Worthing, Iymmington.

In July and August. 'This species can be easily distinguished from reatregella by the narrower fore wings, with their squarer hind margin and straighter costa; also by their paler ground-colour, which causes the markings to appear much more distinet.

The larva feeds on lichens on old fenees, trees, and 
rocks, forming a slight web. Ground-colour dark olive-green; on each segment are two pale streaks, on which are situated the tubereles, which appear to divide them into sections; head, frontal plate, tubercles, and spiracles shining black; ventral surface and legs paler olive. There is a black spot on the outer side of each proleg. The larva pupates in June, in a slight web.

E. M. M. xxi. $101 \%$.

Scoparia angustea, St.

coarctalis, Gn.

(Plate 15. fig. 7.)

Loc. Edinburgh?, Outer IJebrides, Perthshire, Shetland, Milngavic, Ardrossan, Plymouth, Exeter, Bristol, Wirral, Redear, Inddersficld, Scarborough, Norwich, IIastings, Dublin, Howtl, Folkestone.

This widely-distributed species is found in August and September; also in May in the south of Fngland, where the species appears to be double-brookded.

Larva light reddish grey, with shining tubereles, cach bearing a hair; head round and black; dorsal plate dark brown. In galleries, under moss on walls.

Scoparia alpina, Dale. parella, Zell.

(Plate 15. fig. 8, $\delta$ ᄋ .)

Loc. Perthshire, Aberdecnshire, Orkncy, Shetland, Inverness.

This species occurs at high elevations in July.

- Erroneously described as Scoparin cratcgalis. 
Var. gracilalis, $D b l$., is a form occurring at the same localities, in which the markings are more developed and darker.

Loc. Perthshire, Milngavie.

Scoparia pallida, St.

pallidulalis, Gn.

(Plate 15. fig. 9.)

Loc. Isle of Unst, Jidinburgh, Braunton Burrows, Devonshire, $\Lambda$ shley Hill, Stapleton, Bidston Marsh, Brandon, Askham Bogr, Scarborough, Norwich, Aldeby, Ranworth, Iforning, Lyndhurst, Pembroke, Sandwich, Southend, Deal, Folkestone.

This species occurs only in marshy situatiens in July and $\Lambda$ ugust; usually plentiful where it occurs.

Nomophila noctuella, Schiff.

hybridalis, IIb.

(Plate 7. fig. 2.)

Loc. Scotland (common in the soutli-west), Dunoon, Ardrossan, Luss, Marlborough, Plymouth, Devonshire, Bristol, Chester, Ilastings, Suftolk, $\Lambda$ skham Bog, Flanborough IIead, Richmond (York.), Sheffich, Norfolk, Colchester, P'cmbroke, Glamorgan, Carmarthen, Deal, Tolkestone, Ireland.

In July, August, and September. Common everywhere. Variable both in size and colour.

The larva feeds on Polygonum aviculare (knot-grass) in July. Ground-colour warm olive-drab; head dark 
reddish brown; dorsal line dark olive-rlrab, bordered with paler; on each side of the back is a row of large, round, polished, plate-like, black marks, encircled with pale drab; there is also a pale whitish waved stripe below the spiracles, which are black encireled with grey; ventral surface dark olive. The larva forms a tough white cocoon amongst its food-plant.

E. M. M. xiv. 161 .

\section{Odontia dentalis, Schiff.}

(Plate 2. fig. 4.)

Loc. Tavistock, Ilastings, Folkestone, Deal.

This species occurs in July and August.

The larva feeds on the stems and leaf-stalks of Echium vulyare (viper's lougloss). It has the appearance of a full-fed maggot. On the second scyment is a broad dorsal plate, on each side of which are two scabrous spots; there is amother plate on the thirtecnth serment. The ground-colour is yellowish white, covered with black tubereles, each emitting a bristle ; colour of head and plates black. It pupates letween leaves of its food-plant spun together. Ent. iv. 159.

\section{Pyrausta aurata, Scop.}

punicealis, Schiff.

(Platc 2. fig. 11.)

Loc. Scotland, Coombe, Portishead, Bramham, IIuddersficld, Richmond (York.), Sheffield, York, Colchester, Ilastings, Suffolk, Folkestone, Deal, Isle of Wight, Ireland. 
Gencrally common on grassy banks in May, July, and August.

The larva feeds in May and September on calamint and various species of Mentha, under a web. Larva : back dull green; dorsal stripe of the same colour edgert with yellow; spiracular stripe broad and yellowish ; head and second segment pale brown, freckled with black; below the spiracles is a double greenish line; ventral surface pale yellow, dots shining black, ringed with yellow.

A uniform green variety occurs; also a variety with a yellow blotch on the back of the twelfth and thirteenth segments.

E. M. M. xi. 66.

\section{Pyrausta purpuralis, $L$.}

(Plate 2. fig. 12.)

Loc. Scotland (widely distributed?), Arran, Wotton, Brocklcy, Ledsham, Ysccifiog, Rugby, Marlborough, Plymouth, Aldeby, Ketteringham, Booton, Ilorsford, Pembroke, Ireland, IIastingss, Suftolk, IIuddersficld, Bramham, Sheficld, Colchester, Colwyn.

Usually common on railway-banks, slopes, \&c., in May and July.

The larva feeds on Mentha arvensis and aquatica in June and Angnst. IIead brown; ground-colour grey, with black spots, surrounded by white; dorsal and subdorsal stripes yellow.

$\Lambda$ varicty of the larva occurs of a uniform dark brown. 


\section{Pyrausta ostrinalis ?, $\mathrm{Hb}$.} punicealis, Haw.

(Platc 2. fig. 13.)

Loc. Plymonth, Bristol, Iluddersficld, Richmond (York.), Scarborough, Biddleston, Ireland, Scotland?

Oecurs in Junc and again in August; it frequents many of the same localitics as purpuralis, of which it is probably only a varicty. Although the extreme forms of purpuralis and ostrinalis are distinet cnough, yet all the intermediate grades oecur commonly, and it is impossible to say where purpuralis ends and ostrinulis begins. I'le late Professor 'Zeller had a large series in which some specimens were labelled purpuralis, others ostrinalis, evidently not thinking it wise to separate them.

The extreme specimens of ostrinalis differ from purpuralis in the pale yellow band not being divided into spots.

Rhodaria sanguinalis, $L$.

cruentalis, Scriba.

(Plate 3. fig. 1.)

Loc. Troon (Ayrshire)?, Wallasey sandhills, Rhyl, Galway, Cheshire sandhills, New Brighton.

Occurs in May (?) and Angust on sandhills.

Some specimens are much suffused with pink. The larva is red with a white dorsal line; it feeds on Thymus serpyllum in a web, devouring the flowers by preference. 


\section{Herbula cespitalis, Schiff.}

sordidalis, $\mathrm{Ilb}$.

(Plate 3. fig. 2.)

Loc. Scotland (widely distributel), Ardrossan, Arran, Shetland, Orkney, Rugby, Marlborough, Plymouth, Bristol, Wirral, Loggcrheads, Ilastings, Suffolk, Bramham, Richmond (York.), Sheflield, Aldeby, Norwich, Merton, St. Osyth, P'cmbroke, Ircland, Folkestone, Southend.

$\Lambda$ common coast-insect in May and August. The females are smaller and stronger marked than the males. The larve, which are gregarious, live in a web on the lower leaves of Plantago tanceolata and major, also on Salvia.

Ground-colour of larva dull smoky brownish black; head and sccond segment wainscot-brown, freekled with dark brown; dorsal line dark, edged with grey; spiracular stripe dingy ochreous; tubereles polished, black, encircled with grey; spiracles black, with minute white centres; ventral surface and prolegs paler than the dorsal area; the anterior legs tipped with dark brown and encircled with black at the base. The larva pupates in a stiff white cocoon.

E. M. M. xxi. 30.

Ennychia cingulata, $L$.

cingulalis, Schifl:

(Plate 3. fig. 3.)

Loc. Scotland (widely distributed), Dumbarton, Plymouth, Bristol, Clevedon, Wallasey samdhills, Logger- 
heads, Llandrillo, Richmond (York.), Pembroke, Box Hill, Folkestone.

This species occurs in dry meadows, flying in the sunshine, in May and July.

\section{Ennychia nigrata, Scop. anguinalis, IIb. \\ (Plate 3. fig. 4.)}

Loc. Worcombe, Clevedon, Folkestone, Galway.

Occurs during May and August in dry situations amongst rank herbage.

The larva feeds on Mentha arvensis and Thymus serpyllum. Ground-colour dull purple, covered with large black spots, each bearing a fine hair; head bright olivegreen, shining, marked with black; second segment the same, the plate freckled with black; spiracles black; anterior legs green ; the ventral and anal legs are translucent and almost colourless. It forms a cocoon of white silk amongst its food-plants.

L. MI. M. xix. 77 .

Ennychia octomaculata, $F b$.

octomaculalis, Tr.

(Plate 3. fig. 5.)

Loc. Scotland (TVest and N.WV.), IIcbden Bridge, IIastings, Suffolk, Saundersfoot, 13attle, Ireland, Pembroke.

In June and July in woods and also on rough ground. The larva feeds on Solidago viryaurea (golden rod) in a slight web under the leaves.

The head is whitish brown, having a few light brown 
freckles and black ocelli; back cream-colour; dorsal line green; the cream-colour extends lower down the side of the last half of each segment than the first laalf; near the lower margin of this eream-colour is a fine yellowish-green line. It spins a white cocoon among the leaves of its food-plant, in which it passes the winter, pupating the following spring. $\quad$ I. MI. M. xviii. 57.

\section{Agrotera nemoralis, Scop.}

crosalis, $\mathrm{Fb}$.

(Plate 3. fig. 6.)

Loc. IIastings, IIolmbush, Sussex, IIcrne, Battle, Folkestone.

This species occurs in Junc and $A$ ugust, and may be taken by beating hornbeam.

The larva feeds on hornbeam. IIead pale orangebrown; ocelli black; back brownish olive-green; dorsal line darker; the lower parts of the sides, belly, and legs are of a uniform tint of very pale watery olivegreen. It forms a slight cocoon amongst its food-plant. E. M. M. xii. 232.

\section{Endotricha flammealis, Schiff.}

(l'late 3. fig. 7.)

Loc. Plymouth, Clifton, Bristlington, Lundy Island, Colchester, Saundersfoot, IIastings, Lowestoft, Southend, lolkestone, Galway.

Common in woods during June and July; difficult to take on account of its shyness.

The larva feeds on hazel, Lotus mujor, sallow, hornbeam, \&e. It hybernates and pupates in May, cnclosed 
in a cocoon covered with particles of mud, dead leaves, and débris, half sunk in the earth.

Larva : head dark brown; back chocolate-colour; plate on the sceond segment blackish brown; belly brownish ochreous; legs pale greyish drab; anal plate blackish; the front and side margins paler. I. M. M. xix. 149.

\section{Eurrhypara urticata, $L$.}

urticalis, Schiff.

(Plate 3. fig. 8.)

Loc. Scotland(Mid. and S. W. ), Rughy, Marlborough, Plymouth, Monkton, Devon, 13ristol, Chester, Lecds, Richmond (York.), Sheffield, Wakeficld, Norfolk, Colchester, Southend, Deal, Folkestone, Ireland, Pembroke, Glamorgan, Carmarthen.

Common everywhere in Jume and July.

The larva, which feeds in rolled-up leaves of nettle, is of a dirty pale yellow, rather transparent; dorsal stripe green, on each side of which is a yellowish-white line ; head black, with white marks on cach side; dorsal plate greenish, with black markings; spiracles black; legs the same colour as the body. This larva forms a cocoon in October in any convenient situation in which to pass the winter, changing to pupa in the following $\Lambda$ pril or May.

Scopula alpinalis, Schiff.

(Plate 3. fig. 9.)

Loc. Scotland (gencrally distributed at great elevation), IRammoch, Luss, Ardentimy, Invergarry, Inverness, Ross. 
In June and July.

This is an alpine species, occurring only at high elevations in Scotland, where it is usually very common. It is easily disturbed by day, flying a short distance and settling again.

The larva is pale ycllow, with four shining black spots, each bearing a hair on each segment; head fincly freckled; abdominal legrs finely streaked; anterior legrs black. Feeds in June in leaves of a large species of Senecio rolled together. Pupates in the earth.

E. IIofmann.

Scopula Intealis, Hb., Haw., Gn. pascualis, 'Lell.

(Plate 3. fig. 10.)

Loc. Scotland (common to Orkncy), Possil Park, Ruglyy, Marlborough, Catlicart, Devonshire, Clifton, Chester, Yorkshire, Ketteringham, Norwich, Suffolk, Lynn, Cawston, Croydon, Pembroke, IIowth.

A common species in July and August.

The larva fecds on dock, bramble, and thistle. IIead pale yellowish brown, with a few dark brown dots; ground-colour pale green; dorsal stripe broad, dark green, edged with greyish white from segments two to six; spiracular line narrow, greyish white, tubereular spots dark green ; belly pale greyish green ; second segment green; anal flap yellowish. This larva spins a slight cocoon amongst its food.

Lutealis larva is distinguishable from prunalis by the absence of black spots on the second segment. 


\section{Scopula olivalis, Schiff.}

umbralis, Hib.

(Plate 3. fig. 11.)

Loc. Scotland (South-cast), Kenmuir Bank, Southcnd, Rugby, Marlborough, Plymouth, Devon, Bristol, Chester, Yorkshire, Norfolk, Sullolk, Colchester, Hastings, Ireland, Pembroke.

Common everywhere in Junc and July about hedgerows.

The larva fecds on Sambucus nigra, Stachys sylvatica (hedge-woundwort), Urtica dioica, and Humulus lupulus (hop). It hybernates between leaves spun together and continues feeding the following spring.

Ground-colour of the larva pale greenish grey; head and dorsal plate marked with black; dorsal line dark green ; spiracular stripes greyish ; spots black, arranged four on the back of each segment, and a row of triangular ones above the spiracular stripe; legs black.

E. MT. M. xvi. 228.

Scopula prunalis, Schiff.

leucopheceulis, IIb.

(Plate 3. fig. 12.)

Loc. Scotland (widely distriluted), Kenmuir I3ank, Dunoon, Rughy, Mirlborough, Plymouth, Mevon, Bristol, Tirral, 1 [astings, Suflolk, Loggerlicads, Yorkshire, Norfolk, Colchester, Southend, Penbrolse, Ireland.

Common in June and July in hedgerows. 
The larva fecds on Stachys sylvatica, Tencrium scorodonia, Lychnis, marjoram, clder, Veronica officinalis, \&c. Larva : head opaline; back and sides deep transparent green; suldorsal stripes broad, white; legs and abdominal surface paler than the back. Pupates between leaves spun together.

This larva is distinguishahle from lutealis by the distinct black spot on each side of the second segment.

E. M. MI. xvi. 209.

\section{Scopula ferrugalis, $\mathrm{Hb}$.}

(Plate 4., fig. 1.)

Loc. Scotland (South-west), Ardrossan, Plymouth, Excter, Barnstaple, Dartmoutl, Bristol, Chester, Colchester, Ilastings, Suffolk, Rock Ferry, ]3idston, Harrowgate, Scarborough, Norwich, Merton, Cawston, Scilly Isles, Isle of Wight, IIerne Bay, lolkestoue, Dublin, Pembroke.

This common species occurs in August, September, and October, plentifully at ivy-bloom.

The larva feeds on Enpatorium cannabinum (hempagrimony), Stachys pulustris, strawherry, \&c., between leares spun together. It pupates in Oetoher.

Larva: licad pale drab), freekled with brown; dorsal stripe dirk green, bounded on each side by a broad creamy white stripe, eommeneing from the thoracic segments, narrowing towards the extremities; this stripe is followed altemately by green and white stripes; legs pale green; on each side of the second semment are two velvety black spots.

E. MI. M. xiv. 200. 
Scopula decrepitalis, $H .-S$.

(Plate 4. fig. 2.)

Loc. Seotland, Perthshire, Inverness-shire, Argyleshire, Sutherland, Ardentinny.

Very rare; specimens have occurred in May, Junc, July, and August. It is an alpine species.

Mecyna polygonalis, $\mathrm{Hb}$.

limbalis, Tr.

(Plate 4. fig. 3.)

Loc. Bury St. Edmund's, south coast of Kent.

This very rare species has occurred at the abovenamed localities in August. It is extremely common all round the Mediterrancan in $A_{p}$ ril, frequenting grassy slopes, and easily disturbed by day. The fore wings are very variable in colour.

Larva feeds on Cytisus luburnum, also on Cythisus, Geniste, and Spartium, in June and July. Evidently double-brooded. Ground-colour of the larva ashy grey, with rich yellow lateral stripes; three larese black tubercles in a triangle and one above (viz. on each segment); spiracles, head, and prolegs black. In Jume and July.

'Tr.

Mill.

Botys nubilalis, $H b$.

lupulinalis, $\mathrm{Gn}$.

(Plate 4. fig. 4.)

Loc. Isle of Wight, south of London.

Very rare; occurs in May and June. 
The larva feeds in the stems of hop (Humulus lupulus), P'uniceus mileaceus, and allicd plants. It liybernates and turns to pupa the following spring.

Larva : heal dark brown; ground-colour dirty white, with three shining black tubereles on each segment; thoracic plate yellowish, freckled with dark brown, and traversed by a white streak; dorsal and spiracular lines dark; ventral surface paler than the ground-colour.

Note. - nubilalis is easily separated from pandalis by the deeper indentations of the second line, the larger size, and the brown colouring of the males, which oceurs also sometimes in the females.

\section{Botys pandalis, $H b$.}

verbascalis, $\mathrm{Hb}$.

(Plate 4. fig. 5.)

Loc. Marlborough, Almondsbury, Weston-superMare, Sheffield, York, Merton, Suffolk, Southend, Galway.

Common everywhere during June in lanes, hedgerows, and fields.

The larva feeds in a case, formed of a leaf rolled up, on Teucrium scorodonia and brambles (Rubus corylifolius). 'The colour of the back and sides of the larva is dark grey; the dorsal line darker, bordered with pale grey; head grey, marked with black; dorsal plate dark, divided by a pale line. 'Two pale longitudinal lines, one situated on each side of the third and fourth segments. The tubercular spots are large, black, and glossy ; spi- 
racles black; ventral surface greenish grey, spotted with brown. It pupates in its case in Scptember.

E. M. M. xvii. 28.

Note.-This species is double-brooded on the continent.

Botys flavalis, Schiff.

(Plate 4. fig. 6.)

Loc. Halvergatc, Cawston, Isle of Wight, Dover.

This insect oceurs in July, and is fond of dry pastures.

The larva is said to feed on nettle (Urtica urens) and bedstraw (Galium verum).

Botys hyalinalis, $\mathrm{Hb}$.

(Plate 4. fig. 7.)

Loc. Plymouth, Wotton, Clifton, Merton, Thetford, Box Hill.

Common in July in open places in woods.

The larva feeds on Centaurea nigra during the autumn, then hybernates, and pupates in the following May in a slight cocoon.

The ground-colour of the larra is opaque white; head pale red with four black dots; belly yellowish white; spiracles black; thoracic legs rich brown; tubereles shining, with a black dot at the apex.

E. M. M. xxi. 99. 
Botys ruralis, Scop.

verticalis, Schiff, D. L.

(Plate 4. fig. 8.)

Loc. Perthshire, Aberdeen, Scotland (S.E.), Norfolk, Southend, Deal, \&c.

Common in June and July.

The larva feeds on nettles (Urtica urens), rolling up the leaves, in which position it eventually pupates in a slight cocoon. It is shining green, rather transparent, covered with small dark tubereles bearing a single hair ; dorsal line darker than the ground-colour; on each sicle of the dorsal plate is a black spot; head olivebrown.

\section{Botys fuscalis, Schiff.}

cineralis, IIb., Haw.

(Plate 4. fig. 9.)

Loc. Scotland, Paisley, Ardrossan, Clober, Marlhorough, Plymouth, Devon, Almondsbury, Merton, Ketteringham, Cawston, Colchéster, Hastings, Wirral, Logrerehearls, Bradford, II arrowgate, Richmond, Pembroke, Ireland.

Usually common in June and July; a variable species.

The larva feeds on the flowers and seeds of Melampyrum pratense in webs. It forms itself a cocoou in August, away from its food-plant, but does not change to a pupa until the next spring. The ground-colour of the larva is dark greyish brown, becoming paler towards 
the abdominal surface; liead and plate on the second segment glossy brown; the dorsal line is darker than the ground-colour; tubercles shining dark brown; anal plate brown, freckled with black; spiracles black; ventral spots light brown. $\quad$ L. M. M. xvi. 161.

Botys terrealis, $T r$.

borealis, Curt.

(Plate 4. fig. 10.)

Loc. Kirkeulbrienht, Dunoon, Grangre, Jynmouth, Clovelly, Puddington, Loggerheads, Scarborough, Saundersfoot.

This widely distributed species oceurs in July.

It differs from fuscalis in the darker colouring, especially the dark margin round all the wings, and the more pointed apex of the fore wing. 'The larva feeds in September on Solidago virgaurea (golden rod), devouring everything but the stalk. It forms a strong web-like cocoon, in which it passes the winter, pupating in spring.

T'he ground-colour of the larva is rich reddish pink or green; head and anal segment yellowish brown, the former marked with dark brown; the alimentary canal shows through as a dark dorsal stripe; sides variegated with a darker shade of the ground-colour; ventral surface pale; prolegs tipped with a black dot on the outside. E. M. M. xii. 209. - Ent. iii. 184. 


\section{Botys asinalis, $H b$.}

characteralis, Frr.

(Plate 4. fig. 11.)

Loc. Plymouth, Dartmouth, Instow, Bristol, Clifton, Isle of Wight, Pembroke.

In June and July.

The larva feeds on Rubia peregrina (madder). Ground-colour yellowish brown, rather transparent, becoming paler towards the veutral surface; dorsal and subdorsal lines reddish brown, between which is a broad band of olive-brown; head straw-colour, with dark brown markings; spiracles and spots black. It forms a slight cocoon in July, and is sometimes doublebrooded.

E. M. M. ii. 135 . Ent. xi. 190.

Ebulea crocealis, $\mathrm{Hb}$, $\mathrm{Tr}$. ochrealis, IIb.

(Plate 4. fig. 12.)

Loc. Plymouth, Rothesay, Devon, Bristol, Flamborough IIead, Redear, Hastings, Suffolk, Scarborough, Sheffich, Norwich, Gillingham, IIunstanton, Colchester, Soutliend, Deal, Folkestone, Northfleet, Pembroke, Dublin, Wicklow, Galway, IIowtl.

Common in damp situations in June and July.

The larva is dirty yellowish green; dorsal and subdorsal lines dark green; head black, with a few greyishwhite hairs; plate on the second segment dirty white, marked with black; ventral surface paler than the ground-colour; tubercles and spiracles black. It feeds 
on Inula dysenterica (flcabane) in May, and pupates among leaves of its food-plant in a slight cocoon.

Ent. ix. 88.

Ebulea verbascalis, Schiff:

arcualis, IIb.

(Plate 5. fig. 1.)

Loc. Wotton, Folkestone, Sheffield, Norwich, St. Faith's, Colchester, Suffolk.

This species frequents dry meadows in June and July.

'The larva feeds on 'I'ucrium scorodonia; it hybernates in a cocoon, pupating the following spring.

Larva: head pale drab, freckled with darker; second segment the snme colour, with a conspicuous long black mark on each side; dorsal stripe dark green, bordered with white; sides green; spiracular stripe whitish ycllow ; spiracles black; ventral surface pale green.

E. M. M. Xv. 102.

\section{'Ebulea sambucalis, Schiff.}

(Plate 5. fig. 2.)

Loc. Scotland?, Rughy, Marlborough, Plymouth, Sidmonth, Bristol, 13irkenhead, Chester, Colchester, Ilastings, Suffolk, Askham Bogr, Goole, Bradford, IIalifax, Leeds, Norwich, Yarmouth, Lymm, South London, Ireland, Pembroke.

Common nearly everywhere in June and August.

The larva feeds in a slight web on the underside of the leaves of sambucus nigra and convolvulus; it pupates in a slight cocoon. 
Larva: head pale watery green; second segment similar, but with a broad triangular green mark; dorsal stripe dark green, between two wide paler green stripes; segmental folds yellowish; spiracles black; belly and legs watery green; on each side of the front part of the third and fourth segments is a velvety black spot; skin dull, with the exception of the head and second segment.

E. M. M. xiii. 133.

Note.-The larva of sumbucalis can always be separated from that of stachydalis by the black lateral spot, which always oceurs on the third and usually on the fourth segment, and the less glassy appearance.

\section{Ebulea stachydalis, Zinck.}

(Plate 5. fig. 3.)

Loc. Colchester, Ashford, Kingsbury, Hreshwater (Isle of Wight), Brighton, Carmarthen, Pembroke.

Occurs in June amongst Stachys.

It differs from sambucalis in its deeper colouring, smaller and yellower spots, smaller size, and deeper fore wings. The larva feeds on Stachys sylvatica (hedge- . woundwort) in $A$ ugust, spiming the sides of the leaves togrether. The head and second segment are whitish; on the back of the latter is a broad triangulitr green mark; dorsal line green, bordered with white; segmental folds pure white; sides green; belly and legs paler; spiracles black. The whole skin of the larra is lustrous; it spins a cocoon in September, away from its food-plant, in which it passes the winter, pupating in the following spring. $\quad$ E. M. M. xiii. 133. 
Spilodes sticticalis, $L$.

fuscalis, IIb.

(Plate 5. fig. 4.)

Loc. Scotland, Fifeshire, Perthshire, Aberdecn, Instow, Ilfracombe, Dartmouth, Clifton, Wallasey, Suffolk, Bramlam, Ialifax, Redear, Merton, Thetford, Brandon, Colchester, Folkestone, Howth.

Occurs on rough ground and uncultivated ficlds, during July and August.

The larva, which feeds in June on Artemisia vulyaris (mugwort), is dull grey; head and dorsal plate polished, black; dorsal line darker, bordered by a pale line on either side; subdorsal lines paler; spiracular stripe pale sulplutr-yellow, intersected by a dark grey line; dorsal spots black, with a pale centre; spiracles black; belly pale olive-grey. Pupates under ground.

E. M. M. iii. 260 .

Note.-This larva is liable to variation in colouring.

\section{Spilodes palealis, Schiff.}

(Plate 5. fig. 5.)

Loc. Thetford, Colchester, Hastings, Suffolk, Folkestone, Sheerness, Brighton, Sidmouth, Darenth Wood, Dartford, Southend.

This species flies in June and July.

'The larva feels in September on the umbels of the wild carrot (Daucus carota) in a web, which it lcaves when full-fed. It forms an oval cocoon in some convenient situation, in which it passes the winter, not pupating until the following June. 
Larva : ground-colour of the dorsal surface dull dingy green marbled with black; dorsal stripe dark green; tubercles large, black, encircled with yellow ; spiracular region yellow; spiracles black; ventral surface yellowish white; legss black. $\quad$ L. M. M. iii. 260.

Spilodes verticalis, $L$.

cinctalis, 'Tr., D. L.

(Plate 5. fig. 6.)

Loc. Plymouth, Devon, Bristol, Stapleton, Chester, Binglcy, Bishops Wood, Suffolk, Goole, IIuddersfield, Wakefield, Norfolk, Colchester, lolkestone, Brandon, Pembroke, Ireland, Southend, Deal.

Occurs in clover-ficlds in July and August.

The larva is pale green, with three black warts on each segment; head pale brown, marked with darker brown. It feeds on Spartium scoporium and Cirsium arvense in May and Junc. Pupates in a strong thick cocoon covered with grains of sand.

Nolk.

\section{Psamotis pulveralis, $H b$.}

(Plate 5. fig. 7.)

Loc. Ranworth, Folkestone, Isle of Wight.

'This species occurs in July and August in marshy places where reeds, sedges, and rushes grow; it is easily disturbed by day. The best locality (viz. at folkestone) has disappeared owing to the encroachment of the sea.

The undeseribed larva is said to feed in $\Lambda$ ugust on Mentha aquatica. 


\section{Pionea forficalis, $L$. \\ (Plate 5. fig. 8.)}

Loc. Scotland, Kirklec, Ardrossan, Dunoon, Rugrby, Marlborough, Plymouth, ncar London, Bristol, Devon, Chester, Yorkshire, Norfolk, Colchester, Hastings, Suffolk, Pembroke, Ireland.

Common everywhere in May, June, and again in August.

'The larva feeds on eabbage, horse-radish, and other garden plants; often very destructive. It is yellowish green, with darker longitudinal lines and spots, between which are fine white lines; segmentul divisions white; head light brown. It is double-brooded. I'reit. \&e.

Orobena extimalis, Scop.

emecalis, $\mathbf{H b}$.

margaritalis, Schitt., Iib.

(Plate 5. fig. 9.)

Loc. Redlands, Beachamwell, Cambridge, Wicken, Folkestone.

In June and July, frequenting the flowers of the food-plant.

The larva feeds on Sinapis alba (white mustard) and Sinapis arvensis (charlock) in July, under a sort of web, three or four living together and coming out at night to feed on the sced-pods.

Larva: head black, marked with white; a white ring round the neck; the medio-dorsal surface of the second segment is also white; dorsal stripe yellow, succecded alternately by dingy purple and yellow 
stripes; tubercles, spiracles, and dorsal plate black; ventral surface and legs smoky flesh-colour. It forms a cocoon of silk covercd with particles of carth, in which it hybernates, pupating the following May.

Ent. iii. 224.

Orobena straminalis, $H b$. elutalis, Hb. (Plate 5. fig. 10.)

Loc. Lundy Island, Norwich, Wooton, Cawston, Coltishall, Horsford, Colchester, Hastings, Suflolk, Cavan, Killaruey, Ranworth, Red Hill.

This insect frequents damp meadows, grassy places in woods, \&ce, in June and July.

The larva feeds on Barbarca vulgaris, Sinapis arvensis, and other plants in August.

Larva: head black, upper lip bright green; back olive-green; spiracular stripe decp yellow, followed by a paler stripe; spiracles black, ringed with light brown; belly dirty green, paler than the back; along the back and sides are two series of longitudinal white marks; tubereles black; side margins of the plate on the second segment black. In Septenber it forms a cocoon covered with particles of carth, in which it hybernates, pupating the following spring. E. M. M. xix. 127. 


\section{Perinephele lancealis, Schiff. glabralis, IIb. (Plate 5. fig. 11.)}

Loc. Plymouth, Exeter, Barnstaple, Dartmouth, Wotton, Folkestone, Aldeby, Barton, Bendish, Beachamwell, Colchester, IIastings, Suffolk.

Very local; occurs in May and June.

The larva feeds on Eupatorium cannabinum (hempagrimony) in a web during July and $\Lambda$ ugust. It forms a coeoon and hyloernates, pupating in the spring.

Larva: head drab, glossy, speckled with dark brown; the second segment is glossy green above, with a series of black dots; dorsal stripe dark green, bordered on each side with white stripes, followed by a broad green stripe, margined below by a narrow white line; spiracles black; ventral surface and legs watery green; the whole skin shining and semitransparent.

E. M. M. xii. 277 .

\section{Margarodes unionalis, $H b$.}

(Plate 5. fig. 12.)

Loc. Dartmouth, Torquay, Scilly Islands, Gravescud.

Of very unusual occurrence in this country. Common in Southern Europe in June and July, where the larva feeds in autumn on the olive. It is yellowish green, with green stripes and a yellowish-green head. 


\section{STENIIADA.}

\section{Diasemia literata, Scop. \\ literalis, Schiff, D. L. \\ (Plate 6. fig. 1.)}

Loc. Plymouth, Bristol, Pembroke, Glamorganshire, Carmarthen, Suffolk, Exeter, IIampshire.

Occurs in June and again in the middle of $\Lambda$ ugust. The second brood are smaller than the first. 'This species is found on rough ground, where it is easily disturbed, settling again after a short flight.

\section{Diasemia ramburialis, Dup.}

(Plate 6. fig. 2.)

Loc. Lewes, Folkestone, Dover, Coruwall.

This rare species is occasionally taken in June and again in September and October. In Europe it is recorded from Corsica and Austria.

It differs from literata in the darker and less brown ground-colour, the basal silvery band which crosses both wings, the great difierence in the pattern of all the markings, the decp hollow in the outer margin of the hind wings.

Antigastra catalaunalis, Dup.

(Plate 6. fig. 3.)

Loc. Near London, ncar Dover.

In August and September. Occurs in Spain, South. crn lirance, Central India, Canary Islands. 
Easily disturbed by day from herbage on dry rocky ground.

The larva is pale grecnish yellow, with reddish lines and black tubereles; head small, polished, black; shoulder-plate marked with two black spots. It feerls in spring on Linaria spuria.

Mill.

Note.-In the Canary Islands this species must be double-brooded, as fresh specimens occur in April and May.

Nascia cilialis, $H b$.

acutalis, Ev., Gn.

(Plate 6. fig. 4.)

Loc. Cambridge Fens.

Appears in May and Junc.

This species frequents boggy places, and often comes to light.

Stenia punctalis, Schiff.

cetncealis, Dup.

(Plate 6. fig. 5.)

Loc. Plymouth, Sydmouth, Exmouth, Weston-superMarc, Sliefficld, IIastings, Pett, Ventnor, Brighton, Dover.

This species occurs in. June and again in August.

The larva feeds on Lotus corniculatus (bird's-foot trefoil), clover, knapweed, and plantain in the autumn. It hybernates in a slight web amongst its food-plant, and pupates the following May in a tough cocoon covered with bits of leaves \&c.

Larva: skin shiny; ground-colour pale ycllowish 
stone-tint; dorsal area ashy grey, traversed by a dark line; head reddish chestnut; collar dark brown, divided by a paler line; spiracles ringed with brown; dots black, placed on large shining warts.

E. M. M. xxi, 121 .

\section{Cataclysta lemnata, $L$. \\ lemnalis, Schiff., D. L. \\ (Plate 6. fig. 6, ơ $\subsetneq$.)}

Loc. Rugby, Axminster, Possil Marsh, Devon, Bristol, Chester, Bramham, Suffolk, IIastings, IIuddersfield, Wakefichl, Norfolk, Colchester, T'enby, Ireland, Southend, West of Scotland.

Usually common during June and August in the neighbourhood of water.

Larva aquatic; feeds on Lemna minor; inhabits a case formed out of duekweed \&e. It lives through the winter, and pupates in May.

Ground-colour of the larva dull olive; head pale olive-brown; plate on the second segment shining black; dorsal line black; spiracles black; anterior legs pale olive. $\quad$ İ. M. M. xii. 102.

Paraponyx stratiotata, $L$.

straticlata, $\mathrm{Fb}$.

(Plate 6. fig. 7, of f.)

Loc. Rugby, Frome, Stapleton, Bidston Marsh, Ness, Chester, IIastings, Suffolk, Askham Bog, Bradford, Scarborough, Sheffield, Norfolk, Colchester, Red IIill, Ireland, Highgate, Deal. 
Occurs in June and August near water.

The aquatic larva feeds on Anacharis alsinastrum, Stratiotes aloides, \&c.

The larva is furnished with eight rows of "branchice" composed of Heshy filaments of unequal len şth, tapering to a point. Ground-colour pale yellowish olive, marked with a fow small purplish freckles; dorsal stripe darker; head brown, with darker markings; spiracles black; branchix pale grey. It forms a cocoon amongst its food, and is double-brooded.

E. M. M. xii. 161 .

Hydrocampa nymphæata, $L$.

nymphcealis, Schiff., D. L.

(Plate 6. fig. 8, ơ + .)

Loc. Scotland (widely distributed), Rughb, Marlborough, Plymouth, Possil Marsl, Devon, 13ristol, Chester, Ilastings, Suffolk, Bradford, Scarborough, Shefficld, Wakefield, Norfolk, Lyndhurst, Epping, Deal, Pembroke, Ireland.

This species is found in June, and again towards the end of July and August, in the seighbourhood of water.

'The larva, which is aquatic, lives in a floating case formed of leaves of its food-plant, viz. Callitriche verna (starwort) or I'otamogeton natans. It usually pupates under water amongst its food-plant, but sometimes above the surface or on some neighbouring vegetation.

The ground-colour of the larva is light olive-brown; dorsal plate darker. The plate on the second segment 
is light olive, marked with dark brown; head light olive; ventral surface and legs paler than the groundcolour. Double-brooded.

E. M. M. xii. 210. Ent. iii. 368.

Hydrocampa stagnata, Don.

stagnalis, Gn, D. L.

(Plate 6. fig. 9.)

Loc. Scotland (widely distributed), Rugby, Possil Marsh, Axminster, Bristol, Chester, Bramham, Ilastings, Suffolk, Goole, IIuddersficld, Sheffield, Norfolk, Colchester, Deal, Pembroke, Ireland.

Common in most places near water in June, July, and August.

The aquatic larva feeds on Sparganium simplex, mining the reeds in its carly stages, and after hybernation fecding between the leaves united by silk. The ground-colour of the larva is cither bright transparent yellow or olive-yellow; the head pale brown; second segment yellow, marked with brown. It pupates between two fragments of leaf spun together, either partially or entircly submerged, and moored to a floating leaf.

E. M. M. xiv, 101.

\section{ACENIROPODIDA.}

Acentropus niveus, Oliv.

9. hansoni, St.

o. nivosa, St.

(Plate 6. fig. 10.)

Loc. Fifeshire (locally abundant), Loch Leven, York, 
Brandon, Merton, Ranworth, Colchester, IIastings, Aldborough, Haslemere, Shcerness, Peckham, Hampstead, Hyde Park, Ringwood.

Occurs in July and August, flying just over the water at dusk; at rest on the underside of leaves, posts, \&c. over water during the day.

The female is semiapterous.

The larva, which is light green, feeds under water on Potamogeton heterophyllus, perfoliatus, pectinatus, and lucens. When full-fed, in June and July, the larva may be found in silken cocoons, mixed with bits of leaves \&c., in submerged leaf-axils of Potamogeton.

Lint. vi. 153.

\section{PTEROPHORI.}

PTEROPIIOIII)A.

Agdistis Bennetii, Curt.

(Plate 16. fig. 1.)

Loc. Redear, Malden, St. Osyth, Southend, Canvey Island, Shoeburyness, Sheerness.

This species frequents salt marshes in June and August.

The larva feeds on the sea-lavender (Statice limonium) in July, and the second brood in September, which hybernates and continues feeding in the spring. The pupa is suspended by the tail from the food-plant.

The ground-colour of the larva is green, thickly sprinkled with small white dots; the second segment has several horny spikes protruding from the middle in a horizontal direction, the tips and bases of which are 
rosy; the anal segment is yellowish green on the sides, and violet-brown on the back; on the twelfth segment is a rosy horn; the head is yellowish green, with rosy markings; spiracular stripe yellow. Lnt. xvi. 27.

Cnæmidophorus rhododactylus, $F$.

(Plate 16. fig. 2.)

Loc. North Kent, Chattenden, Kingsbury, Mill Hill, Finchley.

This sluggish species occurs in July and August; it sometimes comes to light, and may also be beaten out of rose-bushes.

The larva feeds on the buds of the dog-rose at the end of May and beginning of June; the pupa is attached by the tail to the flower-stem, between the bud and a leaf, united by silken threads.

'The ground-colour of the larva is yellowish green; dorsal line reddish violet, most distinet from the second to the sixth segment, and from the eleventh to the thirteenth; head yellowish green, freckled with brown, and a large black spot on ench cheek; tubereles whitish, bearing a white hair; spiracles reddish brown, ringed with white; prolegs blackish; ventral legs green, tipped with brown; the whole body is covered with short whitish bristles.

Ent, xviii. 275.

Platyptilia ochrodactyla, $H b$.

dichrodactylus, Muiblig.

(Plate 16. fig. 4.)

Loc. Perthshire, Exeter, Iluddersficld, Scarborough, 
Lundy Island, IIorning, Wallascy, Tranmere, Puddington, Colchester, Darlington, Howth.

Occurs amongst rank herbage in Junc and July. The larva feeds in the stems of the tansy (Tanacetum vulgare), and pupates suspended by the tail from a leaf of its food-plant.

The ground-colour of the larva is green; dorsal stripe whitish, traversed by a dark green line; head shining ycllowish green; ocelli black; mouth brown; plates on the second and anal segments yellowish green; subdorsal and spiracular lines whitish, interrupted at the segmental divisions; tubercles black, each bearing a white hair; spiracles dark brown; legs semitransparent, tipped with brown.

Ent. xv, 146. E. M. M. xii. 233.

Var. Bertrami, Rö̈sl. (ochrodactylus, Tgstr.), (Plate 1(i. fig. 3), is a smaller and paler form, with the tips of the fore wings less produced.

Loc. IIendon, Mill Hill, Ventnor, Folkestone, Brandon, Norwich, Thetford, Cawston, Colchester, Hastings.

The larva resembles the type, but feeds on yarrow (Achillea millefolium and Achillea ptarmica).

Platyptilia isodactylus, Zell.

monodactyla, Inaw.

(Plate 16. fig. 5.)

Loc. Teignmouth, Exmouth, Norwich, Pcmbroke, Killarney, Cullunamore. 
Occurs in June and $\Lambda$ ugust in marshy places.

This species differs from gonodactyla in the less distinct costal triangle, the more uniform ground-colour of the fore wings, and the very minute patch of black in the third feather of the hind wing.

The larva feeds in the stems of Senecio aquaticus in May and July, and pupates in its burrow.

The ground-colour of the larva is watery-green, the dorsal vessel showing through; subelorsal stripe dark green, bordered above with white; two white stripes occur along each side; head, anterior legs, tubercles, and plates black; the dorsal plate divided by a line of the ground-colour.

E. M. M. viii. 154.

Platyptilia gonodactyla, Schiff.

trigonodactyla, Haw.

(Plate 16. fig. 6.)

Loc. West and South-west of Scotland, Perthshire, Sidmouth, Bishops Wood, Cawston, Walton-on-theNaze, Clacton-on-Sea, IIastings, Brandon, Bramlam, Flamborough Head, Goole, Cheshire, Southend, Gravesend, Howth, Pembroke.

This species is found amongst coltsfoot in June and August.

The larva occurs in $\Lambda$ pril and May in the flowerheads of coltsfoot (Tussilayo farfara); the second brood of larve probably feed on the underside of the leaves in June and July.

The ground-colour of the larva is whitish; dorsal and subdorsal stripes rosy brown; head and dorsal plate shining black; a few black tubercles, each bening a black hair, are seattered over the dorsal and subdorsal 
areas, also a row of black warts along the spiracular line.

Ent. xv. 33.

\section{Platyptilia Zetterstedti, Zell.}

(Plate 16. fig. 7.)

Loc. Folkestone, Lynmouth (North Devon).

Occurs in June and July.

The larva probably feeds in the stems of Solidayo virgaurea.

This species is distinguished from gonodactyla by its more slender appearance, by the broken dash of dark brown colour along the inner margin of the fore wing, and the broad pale posterior edging of the costal triangle.

Var. tæniadactylus, South. (Plate 16. fig. 8.)

This variety occurs in June and July at Lynmouth (North Devon); it flies at dusk; differs from the type by the narrower wings, the darker brown digital fascia, and the black cilia.

Ent. xv, 34.

$$
\begin{aligned}
& \text { Amblyptilia acanthodactyla, } H b \text {. } \\
& \text { calodactyla, Fb., St., Haw. } \\
& \text { (Plate 16. fig. 9.) }
\end{aligned}
$$

Loc. South and South-west of Scotland, Perthshire, Dunoon, Devon, Exeter, IIuddersfield, Richmond, Scarborough, York, Norwich, Aldeby, Cawston, Cromer, Bidston, Tranmere, Colchester, IIastings, Pembroke, Dover, Folkestone.

Widely distributed in June; casily disturbed by day. 
The larva fecds in autumn and May on rest-harrow (Ononis), hedge-woundwort (Stachys sylvatica), wild basil (Calamintha clinopodium), Mentha, \&c. It pupates suspended from the stem of its food-plant.

The larva is pale green, with two white dorsal and one lateral stripe, plentifully covered with hairs and bristles; head yellowish; mouth darker.

Dr. IJofmann.

The following is a description of a larva bred by $\mathrm{Mr}$. South at Ventnor on Stachys sylvatica, feeding on the flowers and unripe seeds; they produed in September an intermediate form between acanthodactyla and cosmodactyla, which Mr. South considers to be identical with the Plume bred by Prof. Frey from the same plant and named by him cosmodactyla, var. stachydalis.

Description of larva referred to above :- Head pale olive-green; crown and cheeks freekled with blackish; mandibles reddish brown. Ground-colour darkish green; alimentary canal darker. Dorsal tubercles four on each segment, from each of which two bristles of unequal length are emitted; subdorsal, two warts on cach segment, the anterior with two and the posterior with one whitish hair; spiracular, one dark green wart with two whitish hairs on each segment; there are minute blackish bristles senttered over the entire dorsal and ventral areas; dorsal and subdorsal warts seated on linear patches of a yellowish colour; prolegs blackish; anal claspers semitransparent, with greenish tinge.

Pupa attached by the tail to stem of food-plant, generally near the flower-whorl; it is at first of a greenish colour, but changes to an obscure reddish brown; the leg-eases are detached from the abdomen; head truncate; two conspicuous points on back. R.S. 
Amblyptilia cosmodactyla, $H b$.

punctidactylus, Haw.

(Plate 16. fig. 10.)

Loc. Dunoon, Rothshire, Braemar, Perthshire, Exeter, Lynmouth, Dorsetshire, Cardiganshire, Killarney.

Occurs in July and October.

The larva feeds in June and July on the seeds of columbine (Aquilegia vulyaris), meadow cranesbill (Geranium pratense), Stachys sylvatica, Sc.

The larva is dirty green, with a dark green dorsal line, and two interrupted white lateral stripes; tubercles small; head light brown, with darker spots; prolegs black; abdominal legs of the ground-colour. Frey.

In the E. M. M. vol, xxii. p. 1.19, Mr. Porritt gives two descriptions of larvae which he reared on Stachys syleatica, and which produced both acanthorlactyla and cosmodactyla ; he was unfortunately unable to discover which form of larra produced acanthodactyla and which cosmodactyla; but considering that Mr. Porritt observed larve intermediate between the two forms which he described, and that Mr. South bred the intermediate forms of the perfect insects, one would conclude that acumthodactyla and cosmodactyla are forms of the same species.

Oxyptilus distans, Zell. latus, D. L.

(Plate 16. fig. 11.)

Loc. Norfolk, Folkestone, Merton,Thetford, Brandon. Occurs in July and August. 
Var. lætus, Zell. (Plate 16. fig. 12.)

The insect known in this country as latus, Zcll., is a pale variety of distans.

The larva is bonc-coloured, hairy, with a small blackish head and divided dorsal plate; fecds in July on the flower of Andryala sinuata.

Mill.

\section{0xyptilus pilosellæ, Zell. \\ didactyla, Zett. \\ (Plate 17. fig. 1.)}

Loc. Micklcham (Surrey), Belfast.

Occurs in July and August.

Hieracii is said to be darker and with more distinct markings than pilosella; but neither in British nor foreign specimens is there any sufficiently distinguishable character by which to separate them. The descriptions of the larve and their food-plant are almost identical.

The larva feeds on Hieracium pilosella and umbellatum, generally in a company. 'The ground-colour of the larva is dirty yellow or greenish, covered with knobbed bristles and long white hairs; on the back of the abdominal segments is a double row of red or brown longitudinal marks; head honey-yellow.

Frey.

\section{0xyptilus Teucrii, Greening. \\ (Plate 17. fig. 2.)}

Loc. Yarmouth, Brandon, Box IIill, l'olkestone, Warrington, 'lilgate Forest. 
Local, but plentiful where it occurs; it flics over wood-sage in the sunshine in July.

This species is larger than pilosellce ; it can be recognized by the broad fascia-like markings of the fore wings, and the larger pateh of black on the inner digit of the hind wing.

The larva feeds in May and June on Teucrium scorodonia (wood-sage).

The ground-colour of the larva is green or yellowish green ; head yellowish green, with dark brown markings; dorsal line faint pink ; subdorsal line broader, pale rosy ; tubercles brown, bearing short white bristles; spiracles ringed with violet-brown; legs ycllowish grcen, mottled with violet-brown. Lint. xvi. 73.

E. M. M. iv. 16,39 , \& viii. 155 .

0xyptilus parvidactylus, Haw. microdactylus, St.

(Plate 17. fig. 3.)

Loc. Ventnor, Box Hill, l'olkestone.

Occurs in May and June, flying in the sun on chalk downs.

This species differs from any other in its smaller size and darker colour.

The larva fecds in April in the young leaves of Stachys alpina; in autumn in the heads of Marrubium.

The ground-colour of the larva is dirty pale green; on each segment are four black warts, bearing a starshaped tuft of bristles; head and dorsal plate black; the latter divided by a pale line.

Frey. 
Mimæseoptilus phæodactylus, $H b$.

lunadactylus, Haw.

(Plate 17. fig. 4.)

Loc. Exmouth, Teignmouth, Epsom, Leatherhead, Micklcham, Box Hill, Folkestone, Maidstone, Caterham Valley, Croydon, Dover.

This species occurs in July; it flies about dusk, but is easily disturbed by day.

The larva fecds in June and July on Ononis spinosa and repens, eating the términal leaves.

The ground-colour of the larva is green; segmental divisions paler; dorsal line bluish green; head whitish green, marked with black; tubereles black, with a tuft of short white bristles and a long grey hair; legs semitransparent, dotted with grey.

Ent. xvi. 75.

Mimæseoptilus bipunctidactyla, Huw. serotinus, Zell.

(Plate 17. fig. 5.)

Loc. Glasgow, Possil Marsh, Milngavic, Devon, Bramham, Grassington, Redear, Sheffield, Norwich, Merton, Cawston, Rawworth, Wallasey, Brandon, Folkestone, Dover, Howth, 13elfast, Pembroke.

Generally distributed in July and August.

Var. aridus, of British collections, is a pale ochrcous form of bipunctidactyla.

The larva feeds in May and September upon the terminal leaves of Scabiosa arvensis and Galium mollugo. 
The ground-colour of the larva is green, with white hairs; dorsal stripe wide, purplish; head yellowish grecn, marked with black; mouth brown; auterior legs black.

Frey.

Nore.-This description of the larva secms to agree with the larva of plagiodactylus, which is only a varicty of bipunctidactyla.

Ent. xviii. 98.

\section{Mimrseoptilus zophodactylus, Dup.}

loewoii, Zell.

(Plate 17. fig. 6.)

Loc. Bramham, Sandburn, Norwich, Merton, Ness, Burton, IIitchin, Lancashire, Isle of Wight, 'Tilgate Forest, Saffron Walden, Pembroke.

Occurs in August, probably also in Junc. Hodgkinsoni, Greg., is only a slight variety of this species.

The larva feeds from July to September in the green sccd-capsules of Erythrea centauren, which it hollows out, living well conecaled in the interior; it leaves the plant in September to pupate.

The ground-colour of the larva is yellowish green; dorsal and subdorsal stripes dark; segmental divisions deeply cut; head dusky, with two black spots; larva covered with light brown hairs.

A. Schmid.

The following note was kindly sent me by Mr. South; it seems to apply to this larva:-

"In September 1881, I had a Plume-larva sent me from Sussex; it was fecding in the flowers of Erythrea centaureum, but I failed to rear the imago.

"Length 5 lines, taperiug towards anal extremity; head shining yellowish green, smaller than second ser- 
ment. Ground-colonr yellowish green, with a broadish violet dorsal stripe from the third to thirteenth segments inclusive; numcrous short pale grey hairs arranged in four lines along the dorsal and lateral areas, but no perecptible warts. Spiracles dark brown." R.S.

Mimæseoptilus pterodactylus, $L$.

$$
\begin{gathered}
\text { fuscus, Retz. } \\
\text { (Plate 17. fig. 7.) }
\end{gathered}
$$

Loc. Glasgow, Perthshire, Ayrshire, Ardrossan, Exeter, Boroughbridge, Bramham, Doncaster, York, Norwich, Merton, Cawston, St. Faith's, Wallasey, Colchester, Ilastings, Suffolk, Folkestone, Southend, Pembroke, Howth.

This widely distributed species occurs in July and September.

The cinnamon-brown colour and somewliat larger size sufficiently distinguish this species from bipunctidactyla; and from similar coloured forms of monodactylus, its smaller size and narrower wings at once scparate it.

The ground-colour of the larva is green; the segmental divisions yellowish green; head whitish green, spotted with blackish; mandibles brown; dorsal line dark olive-green; subdorsal and spiracular lines whitish; tubercles whitish, with tufts of hair; legs semitransparent light green; the prolegs spotted with brown; the abdominal legs tipped with black.

The larva feeds on the flowers of Veronica chamadiys and, according to Schmid, on Convolvulus arvensis. 
Edematophorus lithodactylus, $T r$.

septodactyla, 'l'r.

(Plate 17. fig. 8.)

Loc. Flamborough IIcad, Redcar, Scarborough, IIunstauton, Colchester, IIastings, Suffolk, Gravesend, Southend, Deal, Pembroke, Galway. day.

Occurs in July and August; it is rather sluggish by

This species can at once be distinguished from monodactylus by the costal spur.

The larva feeds in Jume on the leaves of Inula dysenterica (fleabanc) and Conyza squemosa.

The ground colour of the larva is yellowish green; head pale brown ; mandibles and freckles reddish brown, and a black spot on each check; dorsal strije pinkish, approaching violet towards the edges and bordered with whitish, divided by a yellow line; tubercles pinkish, bearing pale hairs; legs semitransparent greenish.

Ent. xv. 104.

Pterophorus monodactylus, $L$. pterodactyla, IIb., IIaw., I). L.

(Plate 17. fig. 9.)

Loc. Doncaster, IIuddersfield, Marsden Mloor, Kent, Pembroke.

Generally distributed in July, and from September to April; often found at rest on palings.

The larva is found from Junc to September on various specic of Convolvulus, fecding on both leaves 
and flowers; it pupates attached by the tail to its foodplant. 'There are probably two or more broods in the course of the year.

The ground-colour of the larva is dingy green, streaked and spotted with whitish, and slightly suffused with reddish brown; head pale brown; mandibles brown; on each cheek is a black spot; dorsal strije dark green or reddish brown, dilated on the crest of each segment; tubercles paler than the ground-colour, with tufts of pale brown hairs; legs pale greenish brown.

lint. xv. 278.

lint. xviii. 277.

This species may be recognized by the brush-like tufts of appressed scales on the upperside of the hind fect.

P'ter. of California, p. 40.

Leioptilus lienigianus, Zell.

melinodactylus, II.-S.

(Plate 17. fig. 10.)

Los. Norwich, Ringland, Horning, Colchester, I pswich, Deal, Ventnor, Dover.

Oceurs in July amongst its food-plant.

The larva feeds on the terminal leaves of Artemisia vulgaris in May and June; the pupa is attached anally to the underside of a leaf of its food-plant.

The ground-colour of the larva is pale green; dorsal line darker, divided by a pale line; subdorsal line yellowish, interrupted at the segmental divisions; head shining greenish brown, marked with darker brown; tubercles whitish, crowned with white hairs; legs paler than the ground-colour, with dark brown markings.

lint. xy, 105.

E. M. M. viii. 157 . 
Leioptilus tephradactylus, $H b$.

(Plate 17. fig. 11.)

Loc. IIuddersficld, Scarborough, Shefficld, IIastings, Folkestone, Lynmouth, Lake-district, Witherslack.

This species occurs in shady places in woods during July.

It can be separated from lienigianus by the absence of costal spots and its smaller size.

The larva feeds in May and June on the golden rod (Solidayo virgaurea) - when young mining the stems, afterwards cating lioles in the leaves; it pupates suspended by the tail from its food-plant.

'The ground-colour of the larva is yellowish green; head shining, pale yellowish brown, with recldish-brown mandibles and a black spot on each chcek; dorsal stripe whitish, darker towards the centre; subdorsal line interrupted, yellowish; tubercles whitish, with tufts of pale hairs; legrs yellowish green. Lnt. xv. 106.

\section{Leioptilus osteodactylus, Zell. \\ microdactylus, Zett. \\ (Plate 17. fig. 12.)}

Loc. Devon, IIuddersficld, Searborough, Shefficld, Tenby, Hastings, Folkestone, Jynmouth, Lake-district, Plymouth, North Wales.

Occurs in July; may be taken at flowers of the woodsage at dusk.

Mr. South has kindly sent me the following description of a larva which he takes to be osteodactylus :- 
Larva in secd-heads of golden rod (Solidayo virgaurea) in October. Length $1-5$ lines, plump, taperingr towards each end. Ilead smaller than second segment, light brown; with reddish-brown mandibles, and a black spot on each cheek.

Ground-colour whity brown with greenish tinge, and thickly dotted with minute black dots; dorsal strije and subdorsal line palc rosy pink; tubercles inconspicuous, hardly raiscd above the surface of the skin, dorsal two rows (two on each segnent) each cmit a single brownish hair of moderate length. These hairs on the third, fourth, and fifth segments curve forwards, those of other segments backwards; lateral scries consist of one wart on each segment with a moderately long hair; spiracles black; prolegs pale brown. R. S.

Leioptilus microdactylus, $H b$.

(Plate 18. fig. 1.)

Loc. Scotland (S.lE.), Scarborough, Ranworth, Mcrton, II astings, liolkestone, C'anubridge, l'embroke.

In May and June amongst its food-plant.

The larva feeds on hemp-argimony (Eupatorium cannubinum), mining the flower-stem, in which it hybernates, pupating in the cavity the following spring.

The ground-colour of the larva is yellowish white; a scrics of quadrate dark brown markings forms the dorsal stripe, another row of black dots oecurs along the spiracular region; lead pale brown, with darker freckles and mandibles, also a black spot on each check : prolegs tipped with brown, and the upper portion of the anal clasper's spotted with black. Ent. xv. 10:.

E. M. M. xii. 234. 
This species is not unlike osteodactylus, but is much smaller, and has always one, sometimes two, black spots on the costa.

\section{Leioptilus brachydactylus, $T r$.} ctodactylus, Dup.

(Plate 18. fig. 2.)

Loc. Glen Tilt (Perthshire), Norfolk, Westmoreland, Folkestone, Deal.

This extremely rare species has been taken in July.

The larva feeds on the undersides of the leaves of Prenanthes purpurea, also on Lactuca muratis, in May and June.

The ground-colour of the larva is pale dirty green; dorsal stripe darker, on each side of which is a row of tubercles bearing dark bristles, followed by another row bearing one dark bristle and a few small white hairs; a third row oceurs lower down, erowned with white bristles.

Frey.

\section{Aciptilia galactodactyla, $H b$.}

\section{(Plate 18. fig. 3.)}

Loc. Devon, Norwich, Spirham, Colchester, Ipswich, St. Osyth, IIastings, Folkestone, Chattenden, Wieklow.

This species occurs amongst burdock, sbont the borders of woods, in July.

The larrae feed in a company on the undersides of the leaves of burdock (Arctium lappo).

The ground-colour of the larva is pale green, segmental divisious paler; the broad dorsal stripe is whitish, bisected by a fine line of the ground-colour; 
the head is whitish green, with light brown mandibles and a black spot on each check; tubercles crowned with pale hairs.

Ent. xv. 147.

\section{Aciptilia spilodactyla, Curt. obsoletus, Zell.}

(Plate 18. fig. 4.)

Loc. Lundy Island, Freshwater, Ventnor, Brandon.

Occurs amongst its food-plant in July and August.

The larva feeds on the leaves of the white horehound (Marrubium vulgare) in June and July, it also eats the garden variety; pupates attached by the tail to the upper surface of a leaf of its food-plant.

The ground-colour of the larva is green, sprinkled with minute black dots; tubercles whitish, with star-like tufts of white hairs; legs semitransparent green, tipped with brown. Ent. xvi. 28.

\section{Aciptilia baliodactyla, Zell.}

tridactylus, St.

(Plate 18. fig. 5.)

Loc. Folkestone, Dover, Bristol, Ventnor, Box IIill, Caxton.

This species occurs in July and Angust.

The larva feeds in June on Origamum vulyare (marjoram), eating the terminal leaves; it pupates attached by the tail to its food-plant.

The ground-colour of the larva is dingy green; segmental divisions and dorsal line yellowish green; head yellowish green, with brown mandibles and black check-spots ; tubereles whitish, with tufts of white hairs; legs transparent yellowish green. Ent. xvi. 26. 


\section{Aciptilia tetradactyla, $L$.}

leucodactyla, $\mathrm{IIb}$.

(Plate 18, fig. 6.)

Loc. Renfrewshire, Doneaster, Richmond (York.), Searborough, Galway, Dover, Folkestone.

This specics flies at dusk in July and August; it can be easily distinguished from baliodactyla by the dark fringes and costal margin.

The larva feeds in May and June on Thymus serpyllum, Pulmonaria officinalis, Origanum, \&e.

The larva is light green, covered with white hair,

the blackish markings and spots on each segment; spiracular stripe yellow; head yellowish brown. Treit.

\section{Aciptilia pentadactyla, $L$. \\ tridactyla, Scop. \\ (Plate 18. fig. 7.)}

Loc. Devon, Bramlam, Wakcficld, Goole, York, Norfolk, Wallasey, Trannere, Ness, Burton, IIastings, Suffolk, Pembroke, Wicklow, Cork.

This species, which is generally distributed, flics at dusk in June and July.

The larva feeds in May and June on convolvulus (C'alysteyia sepium), eating both leaves and flowers. It pupates attached by the tail to a leaf or stem of its food-plant.

The ground-colour of the larva is green; the dorsal area margined by narrow white lines commencing at the third segment and terminating at the end of eacis 
suceceding segment in a triangular yellow spot; on the ninth segment these spots coalesee, forming a yellow blotch; head shining yellow; face pale greenish; mandibles pale brown; check-spots dark brown; the dorsal and subdorsal tubereles are black, the remainder are of the ground-colour, bearing tufts of hairs; legs semitransparent, tipped with brown.

Eut. xvi. 27.

\section{Aciptilia paludum, Zell.}

(Plate 18. fig. 8.)

Loc. Cambridge fens.

Occurs in June. Flies at dusk.

\section{ALUCITID王. \\ Alucita hexadactyla, $L$. \\ polydactyla, $\mathrm{Hb}$. \\ (Plate 18. fig. 9.)}

Loc. Scotland (widely distributed), Glasgow, Dunoon, Bothwell, Devon, Bramham, Doneaster, IIuddersfield, Shefficld, Scarborough, Lundy Island, Norwich, Merton, Lynn, Cheshire, Colchester, IIastings, Blarney, Wicklow, Pembroke.

This species occurs from July to April, hybernating in outhonses \&c.

The larva feeds on the flowers of the honeysuekle in June. It leaves the food-plant when full-fed and pupates in the ground.

The ground-colour of the larva is reddish pink, be- 
coming paler when nearly full-fed; dorsal and anal plates sonewhat shining; head pale pinkish brown, spotted with darker brown; mandibles dark brown; a few short bristles are scattered over the body. Ent.xvi. 74 .

\section{CHILIDA. \\ Chilo cicatricellus, $\mathrm{Hb}$. \\ strigellus, Tr. \\ (Plate 7. fig. 3.)}

Loc. Dover.

lixtremely rare in July.

'T'he larva is dirty white, rather reddish above. The interrupted dorsal lines are blood-red; head and dorsal plate yellow; anterior legs white, tipped with brown hooks. It feeds during May and June in the lower parts of Scirpus lacustris.

Tr.

\section{Chilo phragmitellus, $H b$. gigantellus, St. (Plate 7. fig. 5, бํ.)}

Loc. Perth ?, Bidston Marsh, Askham Bog, Norwich, Merton, Cawston, Barton Turf, Ketteringlaam, IIastingrs, Suffolk, Southend, Plumstead, Folkestone, Cambridge and Norfolk fens.

F'requents marshes in June and July.

The larva feeds in the stem of Arundo phragmites just below the surface of the ground.

The colour of the back is pinkish grey or light brown, 
the sides flesh-colour, and the belly white; dorsal line narrow, darker than the back; subdorsal stripes paler; head yellowish brown; plates on the second and anal segments piukish brown; tubereles and spiracles black. Lives through the winter, pupating in spring.

E. M. M. vi. 188.

Lint. xvi. 64 .

\section{Schœnobius forficellus, Thenl.}

(Plate 7. fig. 6, ơ q.)

Loc. St. Davids, Redland, Brockley, Stapleton, Bidstou Marsh, Foxton, Little Neston, Burton, Chester, Askham Bog, IIuddersfield, Norwich, Aldeby, Brandon, Horning, Tenby, IIastings, Gravesend, Folkestone, Deal, Killarney.

Common in marshes in June and July.

The larva is greyish green, with darker dorsal stripes; head black; a black spot on the dorsal plate. It feeds in May and June in the young stems of Arundo, Carex, and Paa spectabilis. In Carex it rolls the leaves together; in Poa it feeds in the thin parts of the stems of the former year, which it bites up and uses for a case. It pupates in a cocoon.

Zk., Tr.

Schœnobius mucronellus, Schiff:

straminella, IIb.

(Plate 7. fig. 7, o \&.)

Loc. Kirkcudbright, Norwich, Cawston, Barton 'Turf, Ranworth, Becily, Braemar, Wicken, Galway. 
Flies fecbly at dusk in marshes and damp situations. It is double-brooded, the first brood appearing in June and July, the second in August.

The larva is undescribed, but stated to feed, like the preceling species, in stems of Arundo phragmites.

\section{Schœnobius gigantellus, Schiff.}

gigantalis, Hb.

(Plate 7. fig. 8, $\delta$ ․)

Loc. Diss, Barton 'Turf, Horning, Ranwortl, Southend, Folkestone.

Occurs in marshy situations in July.

The larva is loamy yellow, with shining grey transverse wrinkles; head and dorsal plate shining yellowish brown. In eaptivity the colouring often becomes olive-green.

It lives in May and June in the young stems of Arundo phragmites, which often break and wither away in the parts under water. Pupates in a cocoon.

Tr., Zk.

\section{CRAMBIDE.}

Calamotropha paludella, $H b$.

obtusellus, Sta.

(Plate 7. fig. 4.)

Loc. Ranworth, Horning.

Occurs in moist situations in July.

The larva is shining, with a dark dorsal line cansed by the alimentary canal showing through, aud dark 
spots on the sides of the first segments; liead small and brown.

It feels in Jume and July in the strong outer leaves of Typha latifolice, eating its way between the cells of the leaves down to the roots. It pupates in this cavity.

\section{Platytes cerussellus, Schiff.}

pygmaus, St., Curt.

(Plate 8. fig. 1, o ㅇ.)

Loc. Merton, Brandon, IVootton, IIastings, Suffolk, Plymouth, Gravesend, Southend, Deal, Isle of Wight, Worthing, Portland.

Frequents ficlds in June and July.

'The larva fecls amongst the roots of a short stiff' species of grass. The skin is glossy, but variable in colour, bcing usually flesh-colour, greyish brown, or olive-green; the liead is also variable in colour, usually ycllowish brown with darker markings ; plates on second and anal segments darker. $\quad$ L. M. M. xxi. 86.

\section{Crambus alpinellus, $H b$.}

(Plate 8. fig. 2.)

L,oc. Yarmouth, Deal sandhills, Southisea.

This species frequents sandy places in fir-woods, also coast sandhills in July and August. It is not an alpine insect as its name would imply. It occurs regularly every season, but sparingly. 


\section{Crambus falsellus, Schiff. abruptella, Thub. (Plate 8. fig. 3.)}

Loc. Perth, Edinburgh, Fifeshire, Aberdecn, Plymouth, Stapleton, Ness, 13randon, Cawston, Ranworth, Hastings, Suffolk, Southend, IIaslemere, Lewes, Dover, Brighton.

Occurs in July and August.

The larra lives in silken tubular galleries in thick moss (Barbula muralis and Ancetangium ciliatum) which grows on rocks, walls, \&c. It pupates in its gallery.

The larva is pale grey and wrinkled, with small dark grey tubercles clothed with fine hair, situated on shining, pale grey, oval spots; the head is shining brown, paler at its hind margin; dorsal plate yellowish grey, sometimes brownish, and shining; aual plate polished, of a darker shade of the ground-colour ; spiracles small and black; legs and abdominal surface paler than the back.

Tr.

\section{Crambus verellus, Zinck.}

(Plate 8. fig. 4.)

Loc. Folkestone, Cambridge.

Occurs in July and August.

It differs from falselles in the absence of a white streak below the costa and its general darker appearance.

'The larva, according to $\Lambda$. Schmid, feeds in moss on old fruit-trees. 


\section{Crambus pratellus, $L$.}

matorum, lib.

(Plate 8. fig. 5.)

Loc. Scotland (common), Shetland, Outer IIcbrides, Rugby, Plymouth, 1)evon, Bristol, Chester, Yorkshire, Norfolk, Pembroke, Carmarthen, Ireland, Hastings, Suffolk, Deal, Folkestone, Southend.

A very common species from May to August.

The males are paler than the females. It can be distinguished from other species by the narrow dull white subcostal and central streaks.

Var, alfacarellus. In this variety the fore wings are rather broader, the second line is less angulated, and the ground-colour is white.

The larva feeds amongst roots of grass (Aira flexuosa) in silken galleries. 'The ground-colour is dingy brown; liead brown marked with darker; tubercles dark olivebrown; anterior legs black; spiracles black; plates on the second and anal segments polished. The tubereles give the skin a rough and uneven appearance.

The larva liybernates, and pupates in spring in a slight cocoon among the roots of grass.

E. M. M. xxi. 62.

Crambus dumetellus, $H b$. pratellh, 11b.

(Plate 8. fig. 6.)

Loc. Scotland (east), Bristol, Wallasey sandhills, York, Blubberhouses, IIastings, Pembroke, Box IIill. 
Occurs during June and July on dry hill-slopes.

The distinguishing features of this species are the short costal streak, the long fore wings, and the white central strenk.

The females of this species have yellower fore wings and darker hind wings than the males.

\section{Crambus ericellus, $H b$.}

(Plate 8. fig. 7.)

Loc. Perthshire, Sutherlandshirc, Inverness-shire (common at Invergarry), Ross, Rannoch, Spean Bridge.

This species occurs during July on moors at an elevation of about a thousand feet above the sea. It can be casily distinguished by its dark colouring, the pure white eentral streak, and the narrow dirty yellowishwhite streak along the inner margin of the fore wingss.

\section{Crambus sylvellus, $H b$.}

adipellus, Tr.

(Plate 8. fig. 8.)

Loc. Horning, Ranworth, Killarney.

Oceurs in bogs and marshy meadows from June to August.

Distinguishing character : the white spot which follows the central streak is continuous to the hind margin.

The females are larger and have much darker lind wings than the males. 


\section{Crambus hamellus, Thnb.}

ensigerella, $\mathrm{Hb}$.

(Plate 8. fig. 9.)

Loc. Exmouth, Chester, Scarborough, Haslemerc, Weyloridge, New lorest, Canterbury, Killarney.

Frequents sandy situations and heaths in July and August.

Distinguishing character: the continuous white central streak, toothed at its lower margin.

\section{Crambus pascuellus, $L$.}

(Plate 8. fig. 10.)

Loc. Scotland (local), Rugby, Plymouth, Excter, Bristol, Bidston Marsh, Claughton, Ness, Burton, Bramham, Redear, Shefícld, Lundy Island, Nortolk, IIastings, Deal, Southend, Sufiolk, P'embroke, Ireland.

Frequents damp meadows, woods, and moors in June and July.

Distinguished by the pale head and thorax bordered on each side with brown, the broad white central streak, and the produced tip of the fore wing.

\section{Crambus uliginosellus, Zell.}

(Plate 8. fig. 11.)

Loc. Devon, Bristol, Norwich, Rauworth, Horning, St. laith's, Lyndhurst, Deal, Dartford. 
Occurs in damp meadows in Junc and July.

Distinguished by the white hind wings, and the broad white central streak, which is often divided.

\author{
Crambus furcatellus, Zett. \\ radiellus, Curt. \\ (Plate 8. fig. 12.)
}

Loc. Perthshire, Aberdecnshire, Inverness-shire, Iake-distriet, Wales, Ross-shire, Invergarry, Rannoch, Killin, on Helvellyn and Scawfel.

lirequents grassy mountain-slopes in July and August.

The larva is pale whitish yellow; head ashy grey. It feeds under the club-moss, which grows plentifully wherever furcatellus occurs. $\quad$ E. M. M. xx. 189.

\title{
Crambus margaritellus, $H b$.
}

(Plate 8, fig. 13.)

Loc. Scotland (widely distributed), Invergarry, Outer IIebrides, Bishopton Moss, Exmouth, Salterton, Thorne Waste, Lowestoft, Deal, Galway.

Occurs in woods during June, July, and the beginning of August.

This species differs from furcatellus in its larger size and much broader central streak.

Var, anglicanus has much paler fore wings. 


\section{Crambus pinellus, $L$. pinelella, L, 1), L. (Plate 9. fig. 1.)}

Loc. Scotland (widely distributed, but not common), Dumbarton, Strathglas, Dunkeld, Plymoutl, Possil, Cadder, Exeter, Bristol, Colwyn, Shefficld, Doneaster, Norwich, Surlingham, Headley, Beceles, Merton, IIastings, Suffolk, Bournemoutl, New Forest, Epping, Croydon, Blean Woods, Wolkestone, Pembroke, Killarney, Galway.

Occurs in July and August; but does not fly so readily in the daytime as many species of Crambus. It is best sought for at night, with a lantem, in situations where it is known to occur.

The larva feeds in a silken web amongst the tufts of grass on which it fecds, viz. Eriophorum vaginatum, Aira cespitosa, \&e. After lybernation it pupates in a cocoon amongst its food.

The larva is reddish slate-colour; the head, plates on the second and anal segments, tubercles, and spiracles are shining black.

F. MI. MI. x. ]63.

Crambus myellus, $H b$.

conchellus, Tr.

(Plate 9. fig. 2.)

Loc. Glen Tilt (Perthshire), Bracmar, Abcrdecushire, Rannoch.

This species is found in June and July, and has probably the same habits as pinellus. It is distin- 
guished from that species by the central streak being twiec divided, and by its decper colouring.

The larva fects in silken galleries under moss on stones, in which galleries it hybernates, pupating the following May.

The ground-colour of the larva is earthy brown; head dark brown; plate on the second segment dark brown, traversed by a pale line; tubereles black-brown, situated on raised spots of the ground-colour; spiracles black; anal plate the same colour as the back, but shining.

Ireit.

\section{Crambus latistrius, Haw.}

leachellus, Zinck.

(Plate 9. fig. 3.)

Loc. 'T'cignmouth, Exetcr, Norwich, Cawston, Yarmoutl, Brandon, Blean Wroods, lolliestone, Haslemere, Canterbury, Weybridge, New Forest.

Occurs on damp heaths and coast sandhills in July and August.

This species ('annot possibly be confounded with any other.

\section{Crambus perlellus, Scop.}

dealbellh, Thinb.

(Plate 9. fig. 4.)

Loc. Scotland (widely' listributed), Rugby, Plymouth, lixeter, 13ristol, Bromborough, Puddington, Windsor, luee, Askilam Bog, Richmoud (York.), 'Thorue Waste, 
Isle of Man, Norfolk, Hastings, Suffolk, Folkestone, Deal, Southend, Pembroke, Ireland.

Occurs in fields from May to August.

Var. warringtonellus (Plate 9. fig. 5) is a local varicty of perlellus, all the intermediate stages occurring.

The larva feeds in perpendicular tubular galleries on Aira flexuosa and other lard grasses. It lyybernates and pupates the following spring in a cocoon half sunk in the earth.

The ground-colour of the larva is dirty greyish green, paler on the belly. 'The head and plate on the second segment are light brown marked with darker; spots dark brown, lighter on the sides than the back; spiracles black.

E. M. M. xviii, 129.

\section{Crambus selasellus, $H b$, St. obtusellus, St. (Plate 9. fig. 6.)}

Lac. Bristol, Cheshire, Puddington, Askham Bog, Scarborough, Norwich, Surlingham, Gillingham, Cawston, Ranwortl, IIorning, Hastings, Suffolk, Canvey Island, Pembroke, Belfast.

Common in damp meadows in July and August.

This specics can casily be distinguished from tristellus by its broader and shorter fore wings, its ochreous colour, and the absence of the hind line.

The larva feeds upon Poo maritima and other coarse grasses, inhabiting a green frass-covered gallery, in which it finally pupates, first spimming up the end.

The larva is brown, becoming paler towards the belly ; 
head black; plate on the second segment blackish brown traversed by a paler line; spots large, shining dark brown, becoming paler towards the belly; anal plate light brown; spiracles black. $\quad$ E. M. M. xvi. 41.

\section{Crambus tristellus, $F b$.}

ferruginella, Thab.

(Plate 9. fig. 7.)

Loc. Scotland (abundant), Plymouth, Devon, Bristol, Chester, Yorkshire, Norfolk, IIastings, Suflolk, Folkestone, Deal, Pembroke, Carmarthen, Glamorgan, Ireland.

This very common species occurs nearly everywhere in July and $\Lambda$ ugust. It is extremely variable in colour.

The larra feeds on Aira flexuosa aud other grasses in a vertical silken tube; pupates amongst the roots after hybernating.

The larva is light brown; the liear, plates, spots, and spiracles are glossy black.

E. M. MI. xiii. 1.1.

\section{Crambus fascelinellus, $H b$.}

aridellus, Zell.

$$
\text { (Plate 9. fig. 8.) }
$$

Loc. Yarmouth (coast sandhills and also inland).

'This species occurs in July on sandhills, and is cxtremely sluggish.

The larva, which feeds on Triticum juncenm, lives in a silken gallery under the sand, pupating in a cocoon amongst the roots of grass. 
The larva is shining pearly grey; the fore part of each segment broally banded with darker grey; head shining dark brown; plate on the second segment shining brown, traversed by a pale line, and margined at the back with darker brown; tubereles blackish brown; dots and spiracles black; anal plate brown; legs and ventral surface paler than the dorsal area.

$$
\text { E. M. M. vii. } 160 .
$$

\section{Crambus inquinatellus, Schiff.}

arbustella, Schrk.

(Plate 9. fig. 9.)

Loc. Scotland (S.W.), Perthshire, Plymouth, Bristol, Scarborough, Sandburn, York, Norfolk, Saundersfoot, Hastings, Suffolk, Folkestone.

Frequents dry fields and lreaths in July and August. It can be distinguished from fuscelinellus by its smaller size and narrower fore wings. It is extremely variable in colour and markings.

The larva feeds on the surface of the ground in silken galleries, upon various species of grass. 'The groundcolour is purplish brown or greyish green; head dark brown; plate on the second segment paler; dorsal line dark; tubereles large and darker than the groundcolour; spiracles black.

L. M. AI. xx. 155 .

Crambus contaminellus, $H b$.

inquinatella, $\mathrm{Ib}$.

(Plate 9. fig. 10.)

Loc. Plymouth, Excter, Sea Mills (Bristol), Dee G 2 
Marsh, Pudlington, Denhall, Milford II aven, IIastings, Shecrness, Tilgate Forest, Southend, Gravesend, Deal.

Frequents dry ficlds and salt marshes in July and August.

Distinguished by its dull colour, narrow fore wings, and few markings.

The larva feeds on Poa maritimn and other grasses, in a silken gallery under stones, surrounded by its food.

The colour of the larva is light earthy grey; dorsal line darker; head greyish brown, marked with darker, also the plate on the second segment, both glossy; spots light brown and glossy; spiracles black; a few dark dots are scattered over the shining anal plate; legs tipped with brown hooks.

E. M. M. xv. 38.

Crambus geniculeus, Haw.

inquinatellus, St.

(Plate 9. fig. 11.)

Loc. Scotland?, Plymouth, Devon, Bristol, Wallascy, Christleton, Colwyn, Redcar, Norwich, Brandon, Cawston, IIorning, IIastings, Suflolk, Folkestone, Pembroke, Dublin (coast).

Occurs in July and August.

Distinguished by its small size and the acutely angled transverse lines.

The larva lives on grasses in a silken tube on the surface of the groumd. It pupates in a cocoon.

The crromel-colour of the borly is reddish grey, darker on the thoracic segrments, paler towards the belly; head shining black, witl paler markings ; dorsal plate shining 
black, traversed by a grey line; dorsal line dark brown; tubercles dark brown and glossy; anal plate brown; spiracles black.

E. M. M. xv. 206.

Crambus culmellus, $L$.

strigella, $\mathrm{Fib}$.

(Plate 9. fig. 12.)

Loc. Scotland (abundant), Shetland, IIcbrides, Rughy, Plymouth, Devon, Bristol, Chester, Yorkshire, Norfolk, Suffolk, IIastings, Deal, Folkestone, Glamorgan, Carmarthen, Pembroke, Ireland.

Occurs everywhere in ficlds from June to August.

'The larva lives in upright silken tubes among the tufts of grass on which it feeds (Festuca duriuscula \&c.) and forms a cocoon in its tube for pupation.

The ground-colour of the larva is pale flesh-colour; the head, plates, and spots are of a light glossy cimnamon; the spots are less conspicuous than in most of the genus; each tubercular spot bears two dark brown dots furnished with hairs; spiracles black.

$$
\text { L. M. M. xvii. } 91 .
$$

Crambus chrysonuchellus, Scop. campella, IIb.

(Plate 9. fig. 13.)

Loc. Clifton, IIcnbury, Merton, Thetford, Brandon, Deal, Box Hill.

Occurs in May and June. Fairly common in the south of England. 
The larva fecds in a tubular gallery amongst the roots of Fesluca ovina, pupating the following spring in its gallery.

The ground-colour of the larva is earthy brown; tubereles darker, each bearing a hair; head honeyyellow, with a few scattered hairs; dorsal plate of the ground-colour, narrow, and divided by a pale line.

Gärt.

Stcttin. c. Z.

\section{Crambus craterellus, Scop.}

$$
\text { rorella, } \mathrm{L} \text {. }
$$

$$
\text { (Platc 9. fig. 14.) }
$$

Loc. South of England, Folkestone, Brighton.

Very rare, in June and July.

Var. cassentiniellus. In this varicty there are only eight browi streaks between the hind line and the lind margin, whereas in the type there are nine.

\section{Crambus hortuellus, $H b$.}

(Plate 10. fig. 1.)

Loc. Scotland (common), Rugby, Plymouth, Excter, Bristol, Chester, Yorkshire, Norfolk, Suffolk, Pembroke, Glamorgan, Carmarthen, IIastings, Deal, Folkestone, Southend, Ireland.

Very common in June and July. Rather variable in colouring.

The larva occurs amongst the roots of grass in ficlds, inhabiting a silken tubular gallery. 
The ground-colour of the larva is purplish brown ; head and dorsal plate light brown; the tubercles, which are dark brown, are very prominent; spiracles black. The colouring of this larva varies considerably in intensity.

E. M. M. xvi. 162.

\section{Eromene ocellea, Haw. cyrilli, Costa. (Plate 10. fig. 2.)}

Loc. Dumfries (September), Glamorgan (March), Folkestone (August), Cheshire (February).

This species occurs along the Mediterranean coast. I have taken it at 'Tangier, flying at dusk on the coast sandhills, February 1885 . It can be easily recognized by the row of four metallic dots along the hind margin of the fore wings.

\section{PHYCIDA.}

Anerastia lotella, $H b$.

miniosella, Tr.

(Plate 10. fig. 3.)

Loc. Exmouth, Redear, Yarmouth, Brandon, Malahide, Portmarnock, Ilastings, Suflolk, Deal, Southend, Bournemouth.

Occurs in June and July, in sandy places.

The larva feeds in tufts of grass (Ammophila arenaria, $\& c$.$) , living in a silken gallery just below the surface of$ 
the sand. It pupates in a silken cocoon coated with sand.

The ground-colour of the larva is pale yellow; head pale chestnut; dorsal line faint, reddish; there are also two faint reddish transverse bars on the back of each segment; the plates on the second aud anal sergments are polished; spiracles of the ground-colour. $\Lambda$ few pale hairs occur on the tubereles, also at the extremities of the larva. $\quad$ E. M. M. xi. 186.

\section{Epischnia farrella, Curt. \\ lafauryclla, Constant. \\ (Plate 10. fig. 4.)}

Loc. Yarmouth (sandhills), Lowestoft, Deal.

This species occurs in July, on sandhills.

The larva is said to feed, in a sand-covered gallery, on Anthyllis vulneraria.

\section{Ilithyia semirubella, Scop.} carnella, $\mathrm{L}$.

$$
\text { (Plate 10. fig. 5.) }
$$

Loc. Jixmouth, Iloruing, Folkestone, Isle of Wight, Dover, Box Hill, Sevenoaks.

Var. sanguinella, HJ., is without the pale costal streak.

The larva feeds in a slight web on Lotus corniculatus, and spins a cocoon amongst its food after hybernation.

'The ground-colour of the larva is bronzy black; the 
head and second segment black; lines alternate green and black, indistinct; tubercular dots and spiracles black, ringed with paler; hairs from the tubereles and the extremities of the larva light brown; ventral legs pinkisp.

E. M. M. xvi. 167 .

Myelophila cribrum, Schiff.

cribrumella, Ilb.

(Plate 10. fig. 6.)

Loc. Merton, Thetford, Brandon, Southend, Gravesend.

Occurs in July and August.

The larva feeds in the stems of thistles. It forms a cocoon, in which it pupates the following spring, inside the excavated stem.

The ground-colour of the larva is greyish olivegreen; head and plates on the second and anal segmeuts brownish black; dorsal stripe dark, bordered with white; subdorsal stripes white; spiracles, tubercles, and hairs black.

I. M. M. xv. 258.

\section{Trachonitis pryerella, Vuughan.}

(Plate 10. fig. 7.)

Of this species there are only three known specimens -one taken by Mr. Iiedles, one by Mr. Pryer (after whom it was named), and one by Mr. Howard Vaughan. All three specimens were taken in London in August or September. 
Myelois cirrigerella, Zinck.

(Plate 10. fig. 8.)

Occurs in dry sandy localitics in July. Very rare in this country.

$$
\begin{gathered}
\text { Myelois ceratoniø, Zell. } \\
\text { ceratoniella, lissch. } \\
\text { (Plate 10. fig. 9.) }
\end{gathered}
$$

Loc. Dover, London, Greenwich.

Occurs in grocery warehouses in June.

The larva feeds on the pods of the locust-bean, dried figs, chestnuts, and other fruits.

The ground-colour of the larva is reddish white, covered with reddish-brown tubercles; head brown; dorsal and anal plates with brown warts.

F. $R$.

\section{Nyctegretes achatinella, $\mathrm{Hb}$.}

(Plate 10. fig. 10.)

Loc. Deal, Yarmouth, Lowestoft, Folkestone.

Occurs among "rest-harrow" in July.

Homœosoma sinuella, $F b$.

sinuatus, $\mathrm{Fb}$.

(Plate 10. fig. 11.)

Loc. Plymouth, Exmouth, Tcignmouth, Tenby, Suffolk, Brighton, Folkestone, Sevenoaks, Dover, Southend, St. Margaret's Bay, Gravesend, Pembroke, Howth.

Occurs in June and July. 
The larva feds in the root-stocks of the ribwort plantain (Plantago lanceolata), pupating in a tough black cocoon in its gallery.

The ground-colour of the larva is white, with a faint bluish tinge 'when full-grown, darker between the segments. The head and plates on the second and anal segments are pale brown; the anterior feet black.

E. M. M. xv, 180.

Homœosoma nimbella, Zell., Dup.

nebulella, Dup.

(Plate 10. fig. 12.)

Loc. Exmouth, Wallasey (sandhills), Flamborough IIcad, Scarborough, Yarmonth, Tenby (quarries), Pembroke, Malahide, Howth, Wicklow.

Common among thistles in May and Junc; also in August.

The larva fects in October on the flower-heads of Aster chinensis and other plants. Pupates in a white web.

The ground-colour of the larva is yellow or greenish white, with five broad pale violet stripes; head brownish yellow; dorsal plate with two blackish-brown lateral spots.

Tr.

Fischer.

Homœosoma saxicola, Vaughan.

(Plate 10. fig. 13.)

Loc. Kirkcudbright (coast), Clifton, Islc of Man, Dover, Folkestone. 
Occurs in June and July.

This species differs from nimbella in the longer and narrower fore wings, the costal streak, and the more conspicuous longitudiual white lines; from senecionis by its smaller size, narrower wings, smaller dots, darker colouring of the fore wings, bifurcating costal streak, and by the absence of the second dotted line.

The larva feeds in September on the flower-heads of chamomile. It is greenish, with darker spots and markings. It passes the winter in a cocoon, pupating the following spring.

I. MI. M. vii. 132 .

E. M. M. viii. 68 .

Homœosoma nebulella, $\mathrm{Hb}$.

(Plate 10. fig. 14.)

Loc. Excter, Bristol, Flamborough Ilead, Scarborough, Norwich, Brandon, Merton, Iloming, Yarmouth, St. Margaret's Bay, Malahide, IIowth, Wicklow.

Occurs in July and August.

Can easily be distinguished from bincevella by the indistinctness and lesser number of the spots on the fore wing.

The larva feeds in the lieads of asters, thistles, and other Compositie. It passes the winter in a cocoon, away from its food-plant, and pupates the following spring.

'The ground-colour of the larva is yellow or whitish green, with five pale violet stripes; head and dorsal plate yellowish brown, the latter with a black spot on each side.-Treit. (referred to nimbella by Stainton). 
Description of larva by G. T. Porritt (Ent. xvii. 113) is almost identical.

Baron v. Nolken describes the larva as dirty reddish brown, with a shining blackish-brown head and divided dorsal plate; in flowers of Tanacelum vulyare.

Homœosoma binævella, $\mathrm{Hb}$. petrella, II,-S.

(Plate 11. fig. 1.)

Loc. Rxeter, Bristol, Merton, Brandon, Tenby, Hastings, Southend, Folkestone, Pembroke, IIowth.

Common in the south of England in July.

The larva feeds in the seed-heads of thistle (Cardeus lenceoletus). Then full-fed it leares its food-plant and spins a tough brown cocoon in which it hybernates, pupating in the following spring.

The ground-colour of the larva is pale green, becoming paler towards the ventral surface; dorsal and subdorsal stripes pink; spiracular stripe also pink but interrupted; head bright chestnut; dorsal plate greenish in front, pale brown behind; anal plate blackish.

E. M. M. xv. 181.

Homøosoma senecionis, Vaughan.

(Ilate 11. fig. 2.)

Loc. 'Stapleton, Norwich, Folkestone, Southend, Dover, Chattenden.

Occurs in May and July.

This species is distinguished from nebulella by its 
much smaller size. From binavella the straight dotted second line, independently of other charaeteristics, at once separates it.

The larva mines the stems of the ragwort (Senecio jacobaa).

The ground-colour of the larva is decp purplish brown, the ventral surface slightly tinged with olive; the head and plate on the second segment are deep blackish brown and brightly polished; the rest of the body is ratler shiny, with a faint violet gloss.

E. M. M. vii. 131 .

Ephestia elutella, $H b$.

elutea, Haw.

(Plate 11. fig. 3.)

Loc. Pfymontl, Exeter, Bristol, Wirral, IIuddersficld, York, 'I'enby, Norwich, London, Bromley, Dover, Pembroke, Irclaud.

Occurs commonly in grocers' warchouses, also can be beaten out of thateh in June and July. This species is extremely variable.

'The larva feeds on grocery stores, rlog-biscuits, cloth, sc. Pupates in any conrenient spot away from its food.

The ground-colour of the larva is pale flesh-colour witlıout gloss; the lical, dorsal and anal plates are shining reddish brown; tubercles similarly coloured; on each side of the third and twelfth segments is an ocellated dark brown spot with a white ecntre.

L. M. M. x. 213. 
Ephestia passulella, Bar.

(Plate 11. fig. 4.)

Loc. London and Dover.

Occurs in large numbers in grocers' warchouses in June and July.

The larva fcerls on dried fruits, oilcakc, \&c. It pupates in a cocoon externally covered with frass, \&c., about its food.

The ground-colour of the larva is brownish pink; head reddish brown and glossy; dorsal plate shining black and brown, divided by a pale line; tubereles dark brown and shining; aual plate dark brown; tulereles and dots dark brown; on each side of the third and twelfth segments occurs a black spot with a white centre.

E. M. M. xix. 104.

Ephestia ficella, St., Dougl.

(Plate 11. fig. 5.)

Loc. Glasgow, Leeds, York, Norwich, Dover, London, Dublin.

Common in August and September in cork warehouses.

The larva feeds on cork.

Ephestia ficulella, Bar.

(Plate 11. fig. 6.)

Loc. London, and probally many scaport towns.

Common in grocers' warchouses in August. 
This species can be readily distinguished from ficella by its smaller size and rounded costa.

The larva feeds on dried figs, raisins, \&c.

The ground-colour of the larva is flesh-colour; the head and plates are glossy dark brown; the dorsal, subdorsal, and spiracular lines are pink; the spiracles and large shining raised tubercles are very dark brown; rentral surfaces greyish white; legs tipped with brown.

E. M. M. xvii, 44 .

Ephestia semirufa, St., Haw.

(Plate 11. fig. 7.)

Loc. Exeter, Redland, Norwich, Witherslack.

This species occurs in Junc and July. It has been beaten out of iry and liolly, and also found in grocers' warehouses. It has not yet occurred out of England.

By some this is considered only a variety of elutella.

Euzophera pinguis, Haw.

$$
\begin{gathered}
\text { fischeri, Zell. } \\
\text { (Plate 11. fig. 8.) }
\end{gathered}
$$

Loc. Bristol, Balby, Shefficld, York, Norwich, Cawston, IIastings, Suffolk, Regent's Park, Henley-onThames, Hackney.

Occurs in July and August.

The larva feeds on the bark of the ash, eating out a cell in which it afterwards pupates in a cocoon.

The ground-colour of the larva is deep dull fleshcolour, becoming paler towards the ventral surface 
the interrupted dorsal line is pink; head chestnut, marked with darker brown; thoracic plate pale brown, blotehed at the hind margin with darker; anal plate chestnut; on each side of the third and twelfth serments is a chestnut spot with a pink centre; anterior legs chestnut.

E. M. M. xv. 162.

\section{Euzophera cinerosella, Zell. \\ artemisiella, St. \\ (Plate 11. fig. 9.)}

Loc. Devon, Stapleton, Norwich, Tenby, Pembroke, Isle of Wight.

Occurs in June and July.

'The larva feeds in the stems and root-stocks of Artemisia absinthium (wormwood) ; it forms a cocoon in its cell, in which it pupates.

The ground-colour of the larva is white; dorsal line greyish brown; head dark brownish red; dorsal plate brownish red, darker at the hind margin and disided by a pale line; on each side of the third and twelfth segments is a greyish-brown spot with a white centre; anal plate and anterior legs greyish brown.

E. M. M. ix. 14.3.

Cryptoblabes bistriga, Haw. rutilella, 'Zell.

(Plate 11. fig. 10.)

Loc. Devon, Bristol, Portbury, Bidston, Birkenhend, Doncaster, IIuldersficld, lork, Iforning, IIastings, 
Suffolk, Southend, Folkestone, Lyndhurst, Darenth Wood, Witherslack.

Oecurs in June and July in woods.

The larva fecls on oak-leaves, which it rolls up. It pupates in a brown web.

The head and back of the larva are light brown marbled with darker; the dorsal and subdorsal lines are dark brown, the latter followed by a pale line, then by a broad stripe of dark brown, below which is a broad band of cream-colour traversed loy a brown line; belly and legs drab; tubercular dots black; on each side of the third and twelfth segments is a brown spot with a black centre.

E. M. M. xiii. 111.

\section{Plodia interpunctella, $H$ b.}

(Plate 11. fig. 11.)

Loc. Devon, Clifton, York, Norwich, London, Dover, Dublin.

This species occurs commonly in grain-warchouses and on board ship. I have taken it in mid-Atlantic.

The larva feeds on grain, dried fruits, \&c. It pupates in a loose silken cocoon.

The ground-colour of the larva is pale straw; the dorsal stripe darker; head and dorsal plate rich brown; mandibles and tips of fore legs dark brown.

E. M. M. xvi. 261.

Alispa angustella, $H b$.

(Plate 11. fig. 12.)

Loc. Devon, Redland, Greenhithe, Leatherhead. 
This species occurs in Jume and August.

The larva feeds in the berries of the spindle; it pupates in a cocoon.

The ground-colour of the larva is dull green; plates darker, the dorsal being divided by a pale line, below which on each side is a black spot; dorsal stripe dark green; between the dorsal stripe and the spiracular region are several scries of rust-coloured markings on each segment; ventral surface pale grecn. Varicties of the larva occur of erery shade of light brown and fleshcolour, with corresponding darker markings.

E. M. M. vi. 143.

E. M. M. xvi. 65 .

Five descriptions of this larva to which I have referred are all different. It appears to be extremely variable.

\section{Gymnancyla canella, $H b$.}

depositella, Zinck.

(Plate 11. fig. 13.)

Loc. Plymouth, IIastings, Suffolk, Portsmouth, Southend, Deal, Malahide.

'This species frequents sandhills in July.

The larva fecls in September on Salsola kali, mining the stems during its carlicr stages, afterwards fecding on the leaves in a slight web. It pupates under the sand in a cocoon of silk mingled with sand.

The ground-colomr of the larva is usually dark green, sometimes redish brown, becoming paler towards the ventral surface; dorsal line dark; subdorsal lines paler than the ground-colour; liead light brown, with black 
markings; the ocellated spot on each side of the third and twelfth segments is black with a pale centre.

E. M. M. viii. 163.

Ent. v. 430.

Ent. xvii, 111.

\section{Phycis betulæ, Göze. \\ obtusella, Zinck. \\ (Plate 11. fig. 14.)}

Loc. Clifton, Bramham, Sheffield, York, IIastings, West Wickham, liolkestone, Epping Forest, Tilgate liorest.

Occurs in August.

The larva feeds in May between leaves of birch spun together.

The ground-colour of the larva is coffec-brown or violet-brown; dorsal stripe pale yellow, interrupted; subdorsal stripes yellow; head light brown, with white markings; pupa black and shiny.

\section{Phycis fusca, Haw. \\ carbonariella, Fisch. \\ (Plate 12. fig. 1.)}

Loc. Scotland (widely distributed), Devon, Bidston, Llynhelig, Blubberlouses, Flamborough IIead, Goole, Saddleworth, Norwich, New Forest, IIowth.

Abundant on burnt heatlis in July.

The larva feeds on sallow (in captivity). Groundcolour of the larva olive-black, becoming paler towards the ventral surface; dorsal line black; head, dorsal 
plate, and tubereles polished black; legs black. The larva hybernates, pupating the following spring.

E. M. M. xix. 110.

$$
\begin{gathered}
\text { Phycis adornatella, Tr., Dup., Zell. } \\
\text { dilutella, IHb., D. L. } \\
\text { (1'late 12. fig. 2.) }
\end{gathered}
$$

Loc. Box Ifill, Devonshire, Dover, Galway, Howth.

Occurs in July.

This species differs from ornatella in the groundcolour and in the strongly angulated interrupted second transverse line, and from subornatella by the absence of the pale faseia and generally less distinct markings.

The larva feeds on "wild thyme."

The ground-colour of the larva is olive-black; hearl brown, marked with darker; dorsal line smoky black, edged with paler; subdorsal lines paler; head and dorsal plate polished.

Ent. xvi. 212.

$$
\begin{gathered}
\text { Phycis subornatelia, Dup., Zell. } \\
\text { serpylletorum, Zell. } \\
\text { (Plate 12. fig. 3.) }
\end{gathered}
$$

Loc. Devon, Perth, IIenbury, Westbury, Pembroke, Howtlı, Isle of Man.

Occurs in July and August.

This species differs from ornatella in the decper ground-colour and distinctness of the second transverse line; from adornatella by the white fascia and stronger markings.

The larva feeds on the wild tlyme in a silken web at 
the base of the plant; it pupates in a cocoon in its web.

Ground-colour of the larva dull greenish grey, more yellow on the back; dorsal and subdorsal lines darker; head, dorsal and anal plates dull black.

E. M. M. xvi. 162.

\section{Phycis ornatella, Schiff. \\ criptella, $\mathrm{IL}$., Curt. \\ (Plate 12, fig. 4.)}

Loc. Devon, York, Folkestone, Sevenoaks, Box IIill, Brighton, Howth.

Occurs in July and August.

Larva said to feed on Thymus serpyllum.

Dioryctria abietella, Zinck.

decuriella, Iib.

(Plate 12, fig. 5.)

Loc. Perthshire, $\Lambda$ berdecnshire, Ross, New Forest, Plymouth, Devon, 13rockley, Coombe, York, Norwich, Merton, Cawston, Brandon, Bournemouth, Ringwood.

Occurs on fir trees in June and July.

The larva lives in fir-eones in Oetober; it leaves them in November, and spins a cocoon on the surface of the ground, in which it passes the winter, pupating in spring.

'The ground-colour of the larva is cherry-red, on the sides rather earthy brown; tubercles black; dorsal plate shining black; head round, decp cherry-red.

Dr. Hofmann. 


\section{Nephopteryx spissicella, $F b$.}

roburella, Zinck., D. L.

(Plate 12. fig. 6.)

Loc. Plymouth, Fxeter, Bristol, Bishop's Wood, Bramham, Doncaster, York, Norwich, Merton, IIorsford, IIastings, Suflolk, Lyndhurst, Croyclon.

Occurs commonly in July and $\Lambda$ ugust.

The larva is found in May in a tubular web on oakleaves, in which it afterwards pupates.

Ground-colour of the larva brown, paler on the sides; on each of the five central segments are two white spots; head reddish brown; shoulder-plate dark brown.

Dr. Hofmann.

Nephopteryx rhenella, Zinck.

hostilis, St.

(Plate 12. fig. 7.)

Loc. Worcester, Colchester, Darenth.

'This species occurs in June and July.

The larva feeds on aspen (P'opulus tremula) in a silken tube between rolled-up leases, usually several together; it pupates in autumu in a slight cocoon.

The groumel-colour of the larva is dingy olive-black; the dorsal stripe black; subdorsal stripes grreyish yellow; subspiracular line dirty white; tubereles blackish brown; the ocellated spots on the third and twelfth segments are of the ground-colour ringed with black; anterior legs black; ventral and anal legs of the ground.colour. E. M. M. xvii. 177. 
Nephopteryx genistella, Dup.

ulicelle, H.-S.

(Plate 12. fig. 8.)

Loc. Isle of Wight (Freshwater), Dorer, Portsca.

Occurs in August.

The larva feels in a loose wel) on furze. Larva: dorsal stripe blackish brown, bordered with pale drab, followed by a ragged stripe of deeper reddish drab, followed by a pale stripe bearing the black tubereles; subdorsal stripe broal, dark brown, followed by two narrow drab stripes divided by a ragged brownish stripe; head pale drab, marked with dark brown; on each side of the third and twelfth segments is situated an ocellated spot, whitish grey with a black centre; spiracles whitish; anterior legs reddish brown; ventral legs spotted and tipjed with dark brown.

E. M. M. x. 89.

Pempelia palumbella, $F b$.

contubernella, Ilb.

(Plate 12. fig. 9.)

Loc. Scotland (S.W.), Pymonth, Bristol, Bidston, Haddon, Ness, Sheffield, York, Brandon, Norwich, Ilorsford, St. Faith's, Cawston, Iastings, Croydon, Epping Forest, Bray (Wicklow).

Conmon in July and August on dry heaths.

'The larva feeds during Mareh and $A$ pril on the stems of Polygala chamebuxus in a web near the groumd; it pupates in May in a white web.

The ground-colour of the larva is dark reddish brown, 
with olive lines bordered with paler and reddish-brown stripes; the segments after the fourth have two black spots; head round, shining black; dorsal plate the same.

Dr. Hofmann.

\section{Rhodophæa formosa, Haw.}

peryfuella, Zinck.

$$
\text { (Plate 12, fig. 10.) }
$$

Loc. Norwich, Cawston, Leytonstone, Lewisham, Peckham, Plumstead.

In June and July.

The larva feeds on the leaves of elm and birch between leaves rolled up or spun together.

The ground-colour is dark green freekled with darker; head the same; dorsal and subdorsal stripes dark green bordered with grey; a grey line also occurs between the dorsal and subdorsal lines, and two similar lines about the spiracular region; ventral surface dull green; on each side of the third segment is a white spot with a black centre; tubcreles black; plate on the second segment shining.

This larva is very variable in colour.

$$
\begin{aligned}
& \text { E. MI. M. vii. 14. } \\
& \text { lint. xii. } 206 .
\end{aligned}
$$

Rhodophæa consociella, $H b$.

tromidella, Dup.

(Plate 12. fig. 11.)

Loc. Plymonth, Exeter, Gully, Stapleton, Birkenhead, York, Searborough, Rossington, Norwich, MIerton, 
('awston, IIampstead, IIighgate, Southend, Folkestone, Pembroke.

Occurs in oak-woods in June and July.

The larva is sulphur-yellow, with five brown lines and small black tubereles; head honey-yellow; dorsal plate the same, spotted with brown. It is foumd in May and June in a tubular web between oak-leaves; pupates in a tough cocoon.

Tr., Zell.

Rhodophæa advenella, Zinck.

palumbea, IIaw.

(Plate 12. fig. 12.)

Loc. Purdown, Scarborough, Norwich, Cawston, II astings, Brandon, Southend, IIampstead, Cambridge, Pembroke, Scotland (S. W.).

Occurs in June and July.

The larva feels in May and June on the flowers of Ciratcegus. P'upates in the ground in a slight cocoon. 'The gromel-colour of the larva is bright green with reddish-brown lateral lines; licad reddish brown.

Zk., Tr.

Rhodophæa marmorea, llaw.

epelydella, Jisch., Gn.

(Plate 12, fig. 13.)

Loc. Exeter, Southend, (xully, Clifton, Norwich, IIastings, Brandon, New fiorest, Whitbarrow, Canbridge, Epping Forest. 
In June and July.

The larva feeds on sloe in spring, spinning the leaves together. It pupates in a cocoon amongst its food-plant.

The ground-colour of the larva is dull chocolate; liead and dorsal plate dingy reci, marked with black, shining; on each side of the third and twelfth segments is an ocellated spot, flesh-colour with a black centre; the tip of the anal segment is rather paler than the ground-colour and shining; spiracles flesh-colour; the anterior legs marked with black; ventral legs dingy flesh-colour tipped with brown hooks.

E. M. M. x. 214.

Rhodophæa suavella, Zinck.

porphyrea, Curt., St.

(Plate 12. fig. 14.)

Loc. Clifton, Norwich, Cawston, IIorsford, Brandon, Southend, Epping Forest.

Generally distributed in the south of Lingland in July.

The larva feeds in May and June on stunted sloe and hawthorn in silken galleries. It spins a cocoon in June, either on its foorl-plant or on the ground.

The ground-colour of the larva is chocolate-brown; head dark brown marked with brownish grey; plates on the second and anal segments polished black; ventral legs semitransparent; antcrior legs spotted with black; on each side of the third and twelfth segments is an ocellated spot, brownish grey with a black centre; hairs dark brown.

1. M. M. xii. 13. 
Rlodophæa tumidella, Zinck.

tumidana, St.

(Plate 12. fig. 15.)

Loc. Plymonth, Exeter, Clifton, Portishead Woods, Pen-y-maes, Holywell, Askham Bog, Sandluum, York, IIastings, Ifampstead, Southend, Folkestone.

Occurs in July.

The larva feeds in May and June on oak in a web. It pupates on the ground.

The ground-colour of the larva is purple, with white punctured lines; subspiracular stripe broad, pale brown marbled with white; head and dorsal plate brown, shining, with black freckles.

Treit.

Rhodophæa rubrotibiella, Fisch.

tumidana, Schift:

(Plate 12. fig. 16.)

Loc. Forest IIill, Folkestone, Isle of Wight.

Occurs in July.

The larve live together in a web on oak in June.

Kalt.

Oncocera ahenella, Zinck.

ceneella, $\mathrm{IIb}$.

(Plate 13. fig. 1.)

Loc. Perth, South-east of Scotland, Devon, Almondsbury, Leigh Down (Somerset), Iluddersfield, Merton, Brandon, Hastings, Pembroke (quarries), Deal, Riddlesdown. 
This species occurs usually amongst Hicracium pilosella on rough ground in June and July. It is very variable in colour.

The larva feeds in May on the lower leaves of Helianthemum vulyare and Artemisia campestris, inhabiting a tubular passage. It occurs in sandy places.

A. Sehmid.

\section{GALLERTD E.}

Galleria mellonella, $h$. cereana, $\mathbf{L}$.

(Plate 13. fig. 2.)

Loc. Devon, Leeds, Norwich, Thetford, Wootton, Hastings, Suftolk, Ireland, Folkestone, Deal.

Common in July and August.

The larva feeds ou the wax in bechives. It pupates in a tough cocoon.

The ground-colour of the larva is dirty white with very pale tubercles; head small, heart-shaped, darker than the ground-colour; plate on the second segment honcy-coloured.

Treit.

Aphomia sociella, $L$.

$$
\text { q colonella, } \mathbf{L} \text {. }
$$

(Plate 13. fig. 3.)

Loc. Scotland (common), Norfolk, Plymouth, Lamlash, St. Thomas, Bristol, Wallascy, Burton, Puddington, Ness, Colwyu, Brandon, Goole, Mastings, 
Leeds, Richmond (York), Slicfield, Pembroke, Southend, Deal, Bromley.

In July and August.

The larva greatly rescmbles the last species; the ground-colour is yellowish brown; tubercles brown; plates on the second and anal segments brown; head red. It lives on wax in the nests of hornets and bumblc-becs, inhabiting loug cells.

Treit.

Melissoblaptes anellus, Schiff:

anella, Gin., D. L.

(Plate 13. fig. 4.)

Loc. Yarmouth, Ireland, Deal.

Occurs in July.

'The larva is said to feed, like the former species, in bees' nests.

Melissoblaptes cephalonica, Sta.

(Plate 13. fig. 5.)

Loc. York, London, Dover.

This species, evidently imported, is to be found in warehouses in the eity in $\Lambda$ ugust.

Achroa grisella, Fb.

alvearia, Fb.

(Plate 13. fig. 6.)

Loc. Perth (abumdant), Bristol, IJolywell, IIuddlersfield, Leeds, Shefficld, York, Thetford, IIastings, Bury St. Edmunds, Liverpool, Ireland, Deal. 
Occurs in June and July (May and September, Reaum.).

'The larva resembles Galleria mellonella, but is smaller; it is bone-coloured, with a honcy-coloured head. It lives from September to March in bechives, being often very destructive. In captivity it will eat nearly anything-woor, cork, \&c. It pupates in a tough cocoon.

Reaum. 



\section{N D E X.}

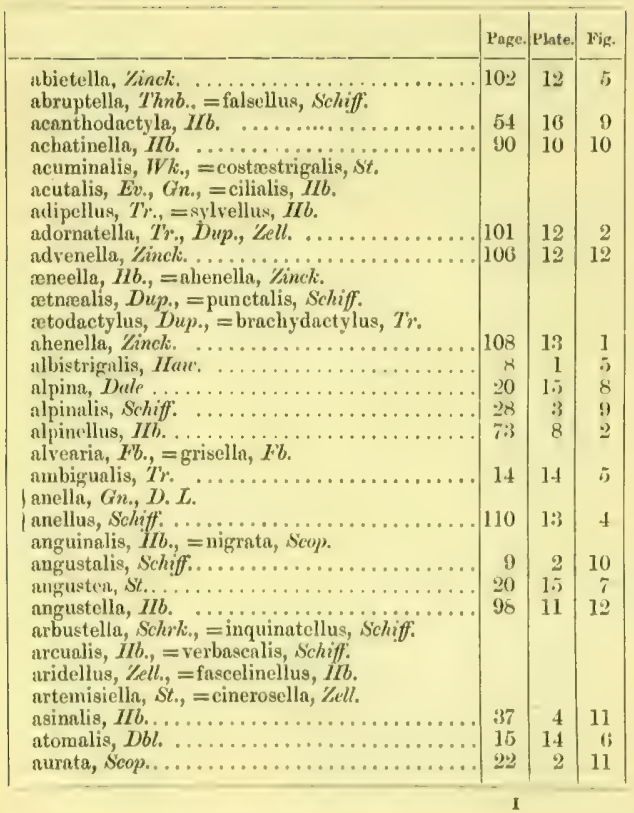




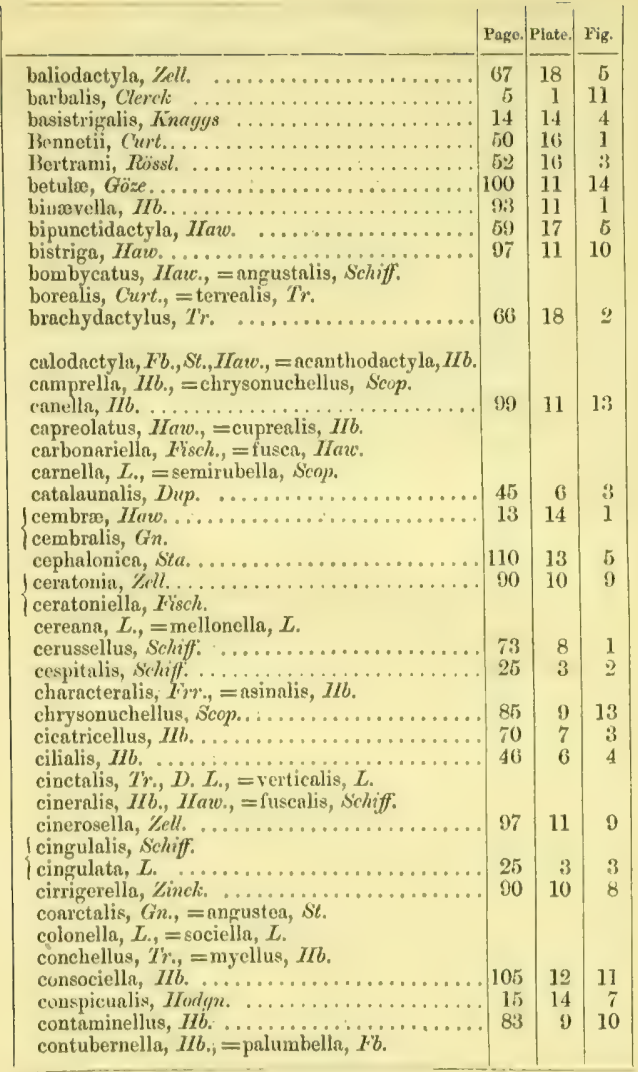




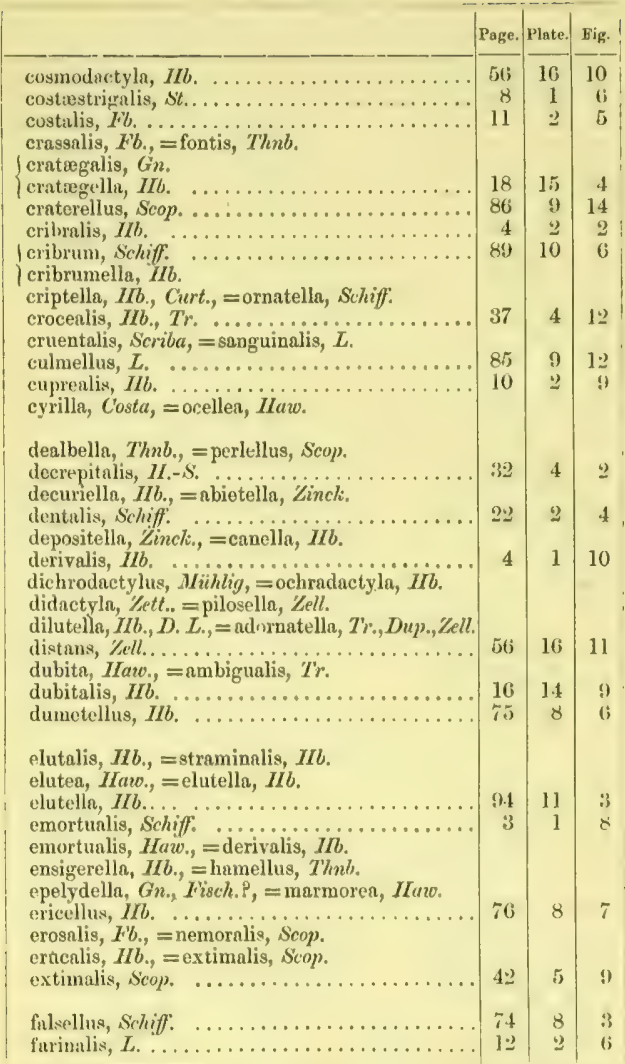




\begin{tabular}{|c|c|c|c|}
\hline & Page. & Plate. & Fig. \\
\hline farrella, Curt. & 88 & 10 & 4 \\
\hline fascelinellus, $I \ddot{I} b$. & 82 & 9 & 8 \\
\hline ferrugalis, $I I b . .$. & 31 & 4 & 1 \\
\hline ferruginella, $T / m b .,=$ tristellus, $F b$. & & & \\
\hline ficelli, St., Dougl. . . . . . . . . . . & 95 & 11 & 5 \\
\hline 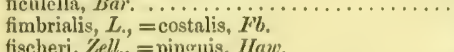 & (20 & 11 & 0 \\
\hline 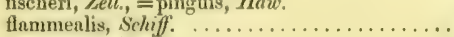 & 27 & 3 & 7 \\
\hline flavalis, Schiff. ........................ & 34 & 4 & (i \\
\hline 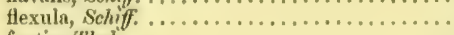 & 1 & 2 & 3 \\
\hline 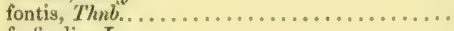 & 6 & 1 & 4 \\
\hline forficalis, $L$. . . & 42 & i) & 8 \\
\hline forficellus, $T h m b . . .$. & 71 & 7 & i \\
\hline formosa, II & 105 & 12 & 10 \\
\hline frequentella, $S t n_{.}$, = mercurella, $I_{4}$. & 78 & 8 & 12 \\
\hline $\begin{array}{l}\text { furcatelliw, Zett. . . . . . } \\
\text { fusca, Iraw. }\end{array}$ & 100 & 12 & 1 \\
\hline fusealis, $I I b b_{,}=$sticticalis, $L$. & & & \\
\hline $\begin{array}{l}\text { fuscalis, Schiff. .................. } \\
\text { fuscus, Retw. = pterodactylus, }{ }_{L} \text {. }\end{array}$ & 35 & 4 & 9 \\
\hline galactolactyla, II & 66 & 18 & 3 \\
\hline geniculeus, IInaw. & 84 & 9 & 11 \\
\hline genistella, Dup. .......... & 101 & 12 & 8 \\
\hline 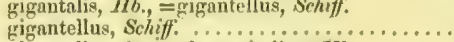 & 72 & 7 & 8 \\
\hline $\begin{array}{l}\text { gigantellus, St., = phrngmitellus, IIb. } \\
\text { glabrialis, ULb., =lancealis, Schiff. }\end{array}$ & & & \\
\hline rlaucinalis, $L . \ldots \ldots \ldots \ldots \ldots \ldots$ & 12 & 2 & 7 \\
\hline gonodactyln, Schiff............ & $5: 3$ & 16 & 6 \\
\hline gracilalis, $106, \ldots \ldots \ldots \ldots \ldots \ldots \ldots$ & 21 & 2 & 1 \\
\hline $\begin{array}{l}\text { grisealis, } 116, \ldots \\
\text { grisella, } F b . \ldots\end{array}$ & $110^{2}$ & 13 & (j \\
\hline lamellus, Thub. & 77 & 8 & 9 \\
\hline hansoni, st., =nivells, Olit. & C0 & 18 & () \\
\hline $\begin{array}{l}\text { hexadactyla, } 1 \text {. } \\
\text { hortuellus, } H J \text {. }\end{array}$ & 86 & 10 & 1 \\
\hline $\begin{array}{l}\text { hostilis, St., }=\text { rhenelln, Zinck. } \\
\text { humidalis, } D b l_{n},=\text { turfosalis, } W k_{\text {. }}\end{array}$ & & & \\
\hline hyaling & 34 & 4 & 7 \\
\hline & & & \\
\hline ingratella, Zell. & 16 & 14 & 10 \\
\hline
\end{tabular}




\begin{tabular}{|c|c|c|c|}
\hline & Page. & Piste. & Fig. \\
\hline $\begin{array}{l}\text { inquinatella, } I I b,=\text { contaminellus, } I I b . \\
\text { inquinatellus, } S t=\text { qenjculeus, II aw. }\end{array}$ & & & \\
\hline $\begin{array}{l}\text { mquinatellus, st., }=\text { genreulus, Haw. } \\
\text { inquinatellus, Schiff. ............. }\end{array}$ & 83 & 9 & 9 \\
\hline 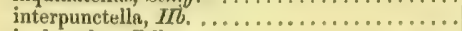 & 98 & 11 & 11 \\
\hline 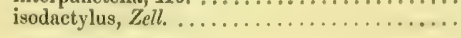 & 52 & 16 & 5 \\
\hline Iætus, $Z e l l . \ldots \ldots \ldots \ldots$ & 57 & 16 & 12 \\
\hline lretus, D. L., = distans, Zell. & & & \\
\hline $\begin{array}{l}\text { lafuuryella, Const., = furrella, cut. } \\
\text { lancenlis, Schiff: ................ }\end{array}$ & 44 & 5 & 11 \\
\hline jatistrius, Iaw. . . . . . . . . . & 80 & 9 & 3 \\
\hline $\begin{array}{l}\text { leachellus, Zinck. } \\
\text { lemnalis, Schiff., } D, L\end{array}$ & & & \\
\hline$\{$ lemnata, $L$. . . . . . . . . . . . . . & 47 & 6 & 6 \\
\hline 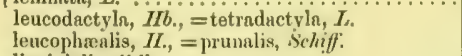 & & & \\
\hline lienigialis, zell................. & 13 & 7 & 1 \\
\hline 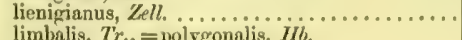 & 63 & 17 & 10 \\
\hline lineolalis, $G$ 'n. & & & \\
\hline 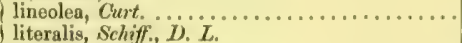 & 19 & 15 & 6 \\
\hline 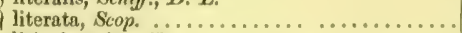 & 45 & 6 & 1 \\
\hline lithodactylus, $i$. .... & 62 & 17 & 8 \\
\hline $\begin{array}{l}\text { loewii, Zell, = zophodactylus, Dup. } \\
\text { lotell } I J b \text {. }\end{array}$ & 87 & 10 & 3 \\
\hline $\begin{array}{l}\text { lunedactylus, IIaw., = phicodactylus, IIb. } \\
\text { lupulinalis, } G n_{n}, D \cdot L_{0},=\text { nubilalis, } M b \text {. }\end{array}$ & & & \\
\hline lutealis, IIb., IIaw., Gn............... & 29 & 3 & 10 \\
\hline margaritalis, Schiff, $F^{\prime} b_{.}$, = extimalis, Scop. & & & \\
\hline 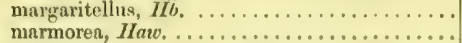 & $\begin{array}{r}78 \\
106\end{array}$ & $\begin{array}{r}8 \\
12\end{array}$ & $\begin{array}{l}1.3 \\
13\end{array}$ \\
\hline melinodactylus, $I I-S_{\text {. }}$, =lienigianus, Zell. & & & \\
\hline mellonelln, $L . \ldots \ldots \ldots \ldots \ldots \ldots \ldots \ldots$ & 109 & 13 & 2 \\
\hline $\begin{array}{l}\text { mercurella, } L \text {. } \\
\text { mercuriellus, Zinck., }=\text { truncicolelin, sta. }\end{array}$ & 18 & 15 & \\
\hline 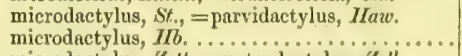 & 05 & 18 & 1 \\
\hline $\begin{array}{l}\text { microdactylus, Zett., =osteodactylus, Zcll. } \\
\text { miniosella, Tr, =lotellh, IIIb. } \\
\text { monodactyln, IInw.?, = isodactylus, Zell. }\end{array}$ & & & \\
\hline 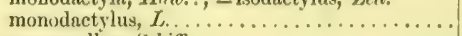 & 62 & 17 & 9 \\
\hline mucronellus, Schiff. .............. & 71 & 7 & 7 \\
\hline
\end{tabular}




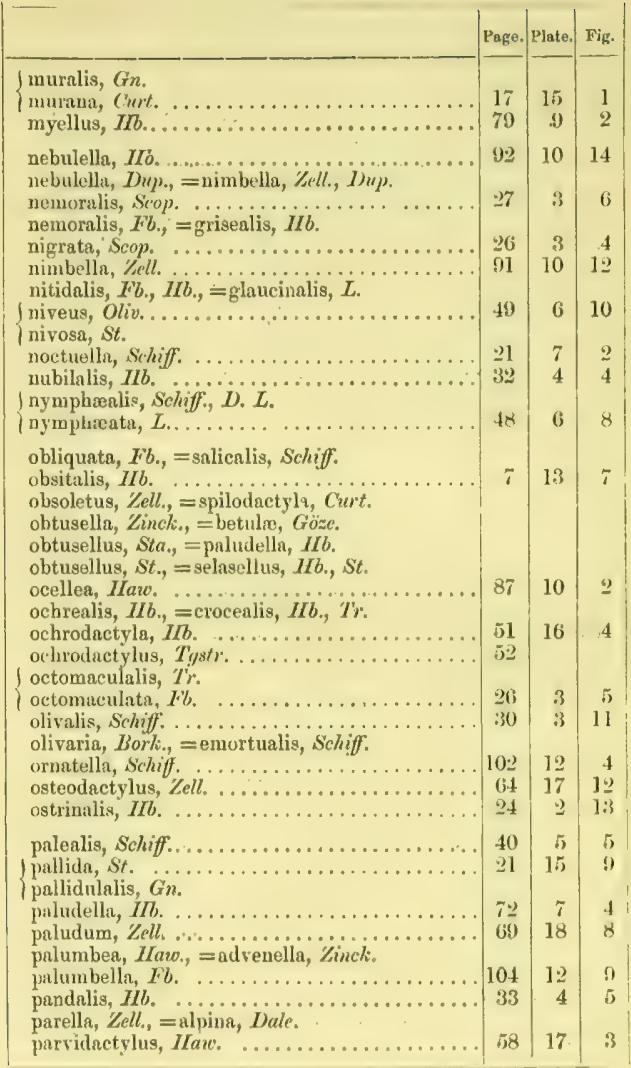




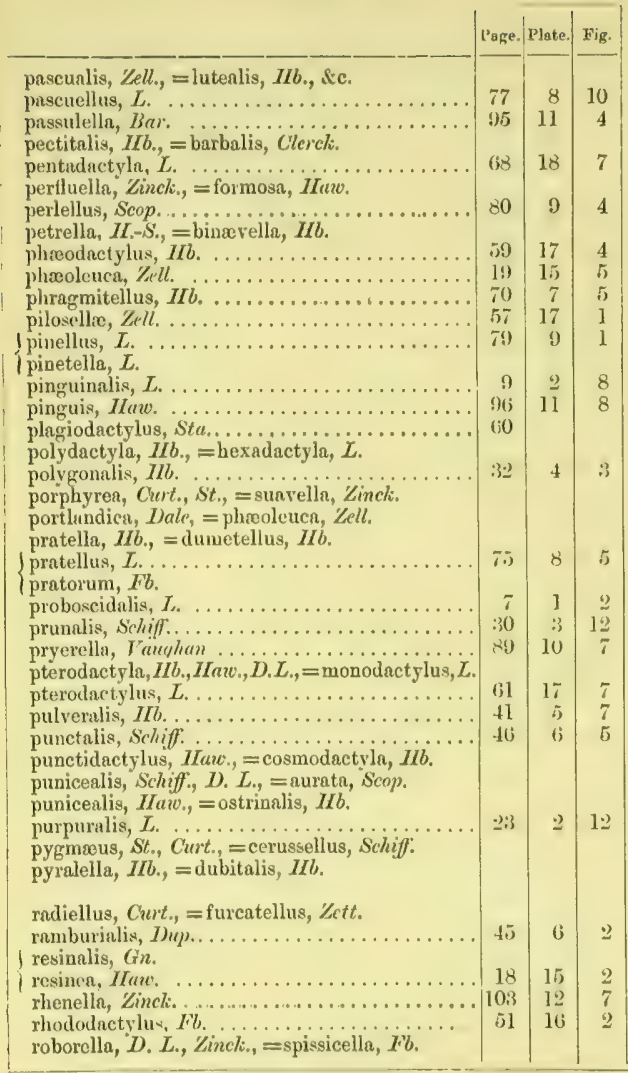




\begin{tabular}{|c|c|c|c|}
\hline & Page. & Plate. & Fig. \\
\hline $\begin{array}{l}\text { roselln, } L ., D . \\
\text { rostrnlis, } L\end{array}$ & 6 & 1 & 3 \\
\hline 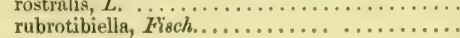 & 108 & 12 & 16 \\
\hline $\begin{array}{l}\text { ruralis, Scop, } \\
\text { rutilella, Zell., = bistriga, Haro. }\end{array}$ & 35 & 4 & 8 \\
\hline salicalis, schiff.. & 5 & 1 & 1 \\
\hline sambucalis, Schiff. . & 38 & 5 & 2 \\
\hline 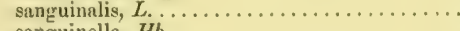 & 24 & 3 & 1 \\
\hline sanguinella, $11 b, \ldots \ldots \ldots \ldots \ldots \ldots \ldots \ldots$ & $\begin{array}{l}88 \\
91\end{array}$ & 10 & 13 \\
\hline 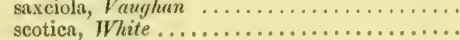 & 14 & 14 & 3 \\
\hline selasellus, IIb., St. . . . . . . . . . . . . . . & 81 & 9 & 6 \\
\hline$\ldots \ldots \ldots \ldots \ldots \ldots$ & 88 & 10 & $\Rightarrow$ \\
\hline semirufa, st., IIavo.? $\ldots \ldots \ldots \ldots \ldots \ldots \ldots \ldots$ & 96 & 11 & 7 \\
\hline $\begin{array}{l}\text { senecionis, Vaughan } \\
\text { septodactylus, } T_{r,}=\text { lithodactylus, } T_{n} . \ldots \ldots \ldots\end{array}$ & 93 & 11 & 2 \\
\hline sericealis, Scop. $\quad \ldots \ldots \ldots \ldots \ldots \ldots \ldots$ & 1 & 1 & 9 \\
\hline $\begin{array}{l}\text { serotinus, Zell., = bipunctidactyla, Haw. } \\
\text { serpylletorum, Zcll., = subornatella, Dup., Zell. } \\
\text { sinunta, } F^{\prime} b .,=\text { llexula, Schiff. }\end{array}$ & & & \\
\hline $\begin{array}{l}\text { | sinuatus, } 1 \% . \\
\text { sinuelle, } F b \ldots \ldots \ldots\end{array}$ & 90 & 10 & 11 \\
\hline sociclla, $L . \ldots \ldots \ldots \ldots \ldots \ldots$. . . . . . & 109 & i3 & 3 \\
\hline $\begin{array}{l}\text { sordidalis, IIb., = cespitalis, Schiff. } \\
\text { spilodactyla, Curt. ............. }\end{array}$ & 67 & 18 & 4 \\
\hline spis: icella, $F$. . . . . . . . . . . . . & 103 & 12 & (i) \\
\hline $\begin{array}{l}\text { stachydalis, Zinck. } \\
\text { istagualis, Gn., } D . L_{0}\end{array}$ & 39 & 5 & 3 \\
\hline \{ staguata, Don ...... & 49 & (i) & 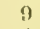 \\
\hline sticticalis, $I$. . . & 40 & 5) & 4 \\
\hline 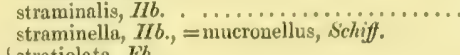 & 43 & 5 & 10 \\
\hline $\begin{array}{l}\text { | stratiolata, } F b . \\
\text { istratiotata, } L . \ldots \ldots \ldots \ldots \ldots\end{array}$ & 47 & 6 & 7 \\
\hline 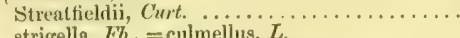 & 10 & & \\
\hline $\begin{array}{l}\text { strigella, } F b .,=\text { culmellus, } L \text {. } \\
\text { strigellus, } T r .,=\text { cicatricellus, } I I b \text {. }\end{array}$ & & & \\
\hline survelin, Zinek, .................. & .107 & 12 & 14 \\
\hline 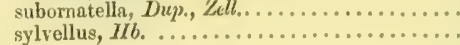 & .101 & $\begin{array}{r}12 \\
8\end{array}$ & $\begin{array}{l}3 \\
8\end{array}$ \\
\hline ts, South & 54 & 16 & 8 \\
\hline farsic & & & \\
\hline & 3 & 1 & 2 \\
\hline
\end{tabular}


tephradactylus, $I I b$.

terrealis, 'i'r.

tetradactyla, $I$.

'Tencrii, Gircening

tridactyla, Scop., = pentadactyla, $\boldsymbol{S}$.

triclactylus, St., = baliodactyli, \%ell.

trigonodactyla, IIrw., = gonodactyla, srkiff.

tristellus, $F^{\prime} b$.

truncicolella, Sta.

tumidana, Schiff., =rubrotibiella, Fisch.

tumidana, Sto, =tumidella, Zinck.

tumidella, Dup., = consociella, IIb.

tumidella, Zinck. . . . . . . . . . . . . . . . . . . 108

turfosalis, $W t_{t}$

ulicella, $I I_{\mathrm{u}}-S_{\mathrm{s}},=$ genistell $\mathrm{\Omega}, D_{u p}$.

uliginosellus, Zell.

ulmella, Dale

umbralis, IIb., =olivalis, Schiff

unionalis, $I I b$.

\} urticalis, Schiff.

urticata, $L$.

\begin{tabular}{|c|c|c|}
\hline Page & Plate. & Fig. \\
\hline 64 & 17 & 11 \\
\hline 36 & 4 & 10 \\
\hline 68 & 18 & (i) \\
\hline & 17 & 2 \\
\hline 82 & 9 & 7 \\
\hline 10 & 14 & 11 \\
\hline 108 & 12 & 15) \\
\hline 9 & 1 & 7 \\
\hline 77 & 8 & 11 \\
\hline 15 & 14 & 8 \\
\hline 44 & 5 & 12 \\
\hline 28 & 3 & 8 \\
\hline 38 & 5 & 1 \\
\hline 74 & 8 & 4 \\
\hline 41 & 5 & 6 \\
\hline 81 & 9 & 5 \\
\hline 13 & 14 & 2 \\
\hline 54 & 16 & 7 \\
\hline 60 & 17 & 6 \\
\hline
\end{tabular}

verbascalis, $I H b .,=$ pandalis, $I I b$.

verbascrlis, Schiff.

verellus, Zinck.

verticalis, $L_{\ldots} .$.

verticalis, Schiff, $D . \mathcal{L}_{\text {, }}$ = ruralis, Scop?. $_{\text {. }}$

warringtonellus

Zelleri, $W$ K.

Zetterstedti, Zell.

zophodactylus, Dup.

Printed by Tayson anb Francts, Red Lion Court, Fleet Street. 


\section{CORIRECTIONS IN PLATES.}

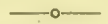

Plate 1. fig. 7, for Shrankia read Tholomiges.

" 7. „5, for phragmittelus rend phragmitellus.

" 9. , 7, for pratellus read tristellus.

"11. " 5, for picella read ficella.

" 13. "6, for Ochroa read Achrœa.

"14. „ 6, for var. atomalis read Scoparia atomalis.

"15. " 1, for nunana read murana.

" 17. "6, for zophrodactylus read zophodactylus. 

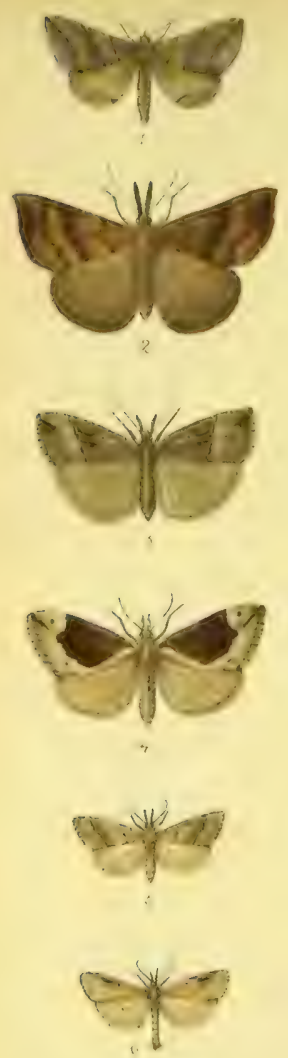

1. Thadopa saícalis.

2. Hypena proboscialis

3 Hypena rostmalis.

4 Bomolocha fontis

5. Hypenodes albistridahs.

6. Hypenodes corlaestinçahs.
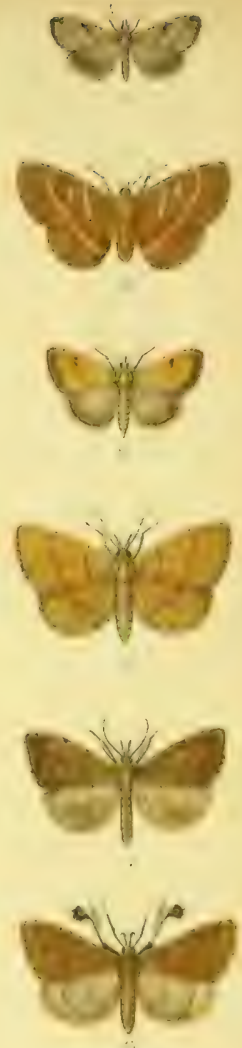

\%. Shrarikua turiusahn

8. Lancloonalha emorlualıs.

9 Ruvula sericealıs.

10. Hemmia demivalis

11. Pechypogon barbatis

12. Zanclognatha tarsiponrahis 


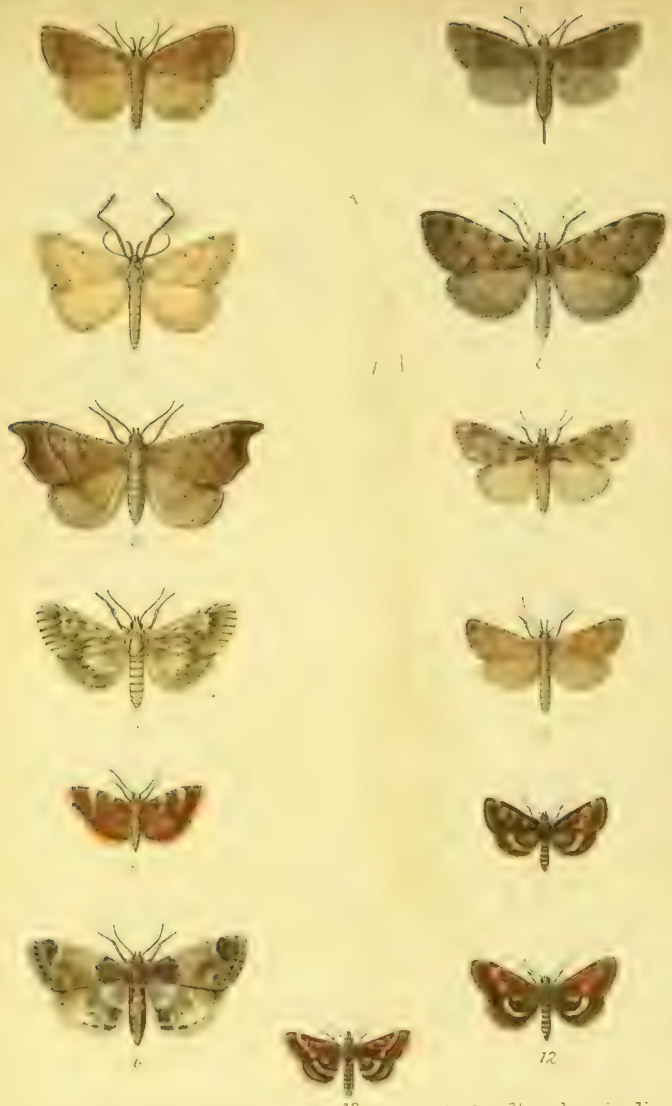

- Zancioenatha griseális:

7. Herrninia crmbrelis

1. Pysalis olaucinalis 8. Aplossa minquinatia

9. Aollossa cuprealis

3 Aventia flexula.

4 Odontia dentalis

10. Cledeobia ansustahs

3. Pyrahis costahs

6. Pyralis farmahs

11. Pyrausta anrata

12. Pycausta purpuralis 


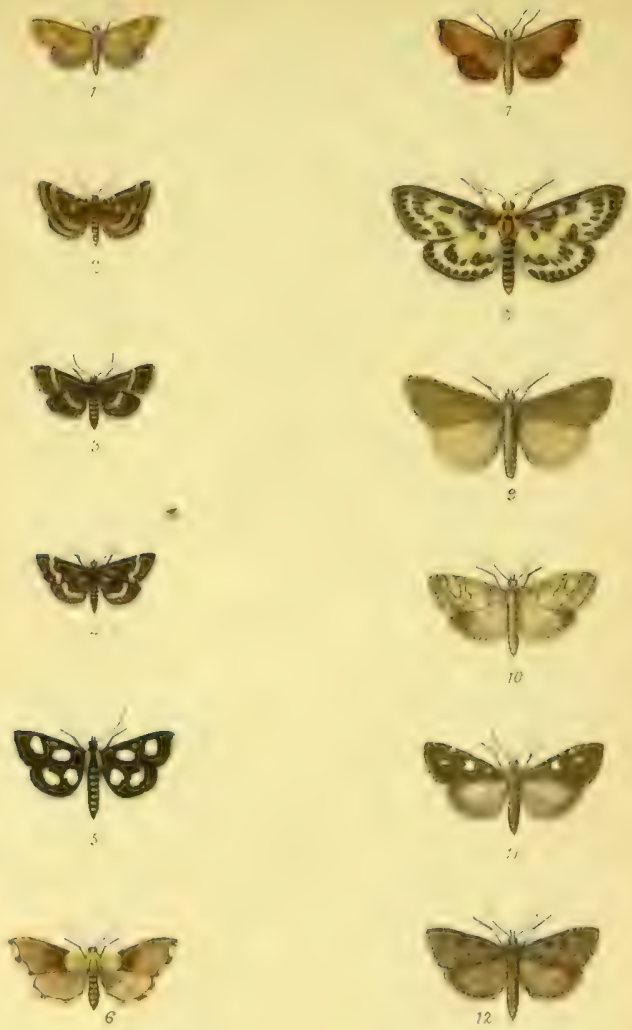

1. Rhodaris sanouinalie

Herbula cespitalis

3. Ennychia cirigulata.

4 Ennychia riorata.

5. Ennychid octomaculata.

6. Aoxotera nemorahis

W Furhise uh

7. Findotmcha fl. men

8. Jirrhypara ..

9. Scopula alp...

10. Scopula luterin:

1i. Scopula ohvi

$12 \ldots$; . . ... 

Bntiom Pyz:alider \&ce
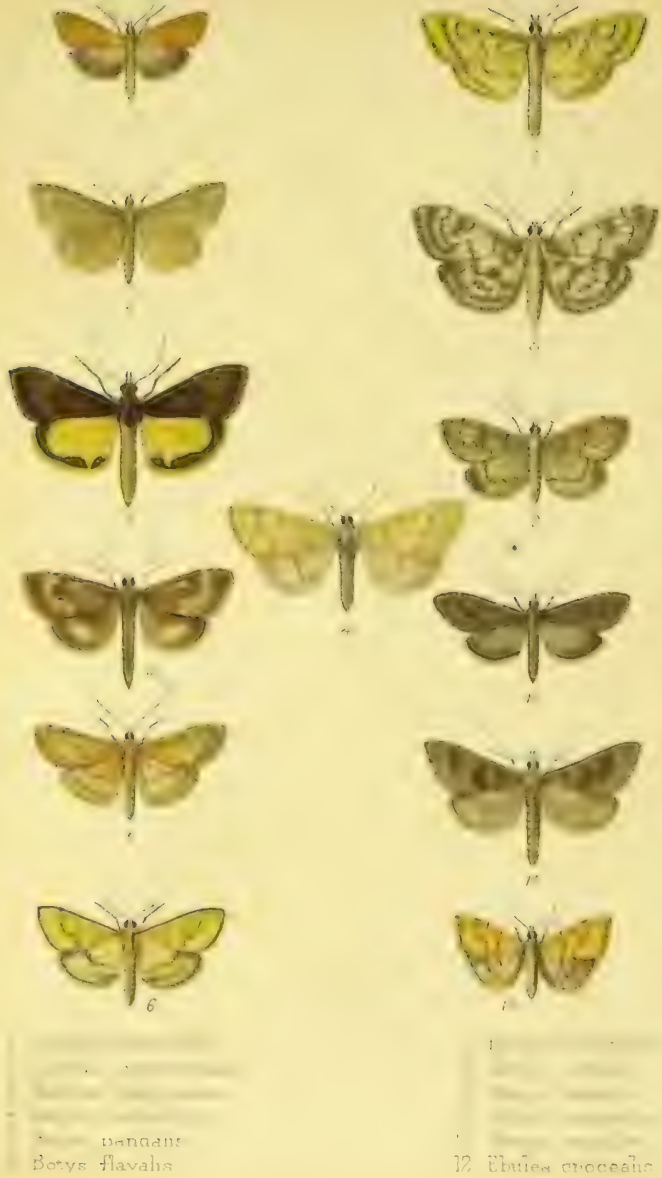


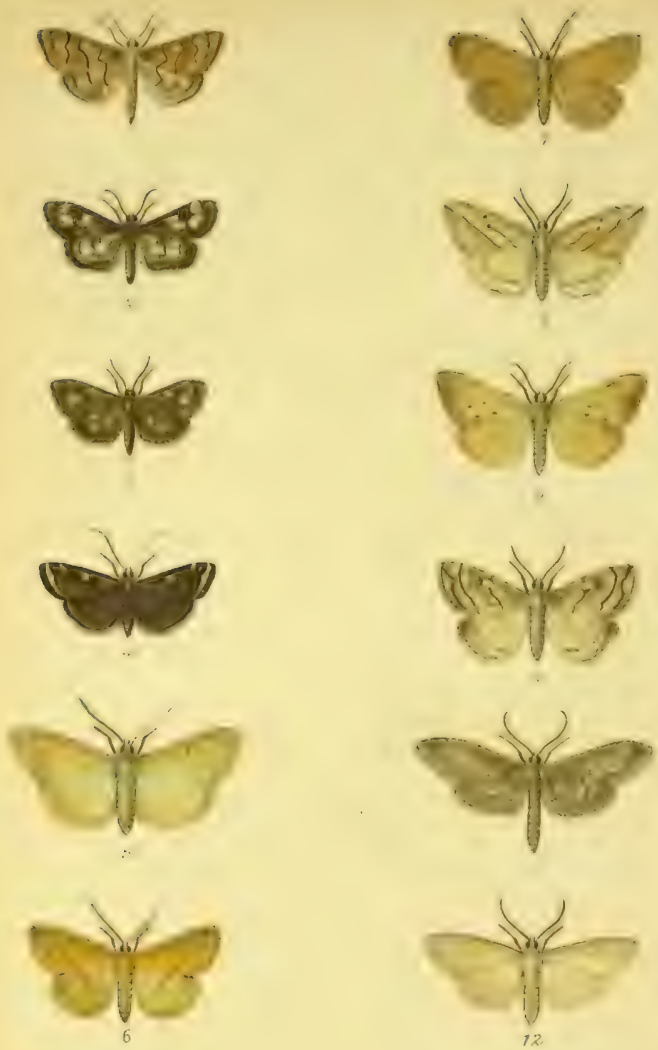

\section{Fibule smpthasealis}

2 Ebulea sambucalis.

3 Ebulea stachyddis.

4. Spilodes sticticalis.

o. Spilodes palealis

6 Sinlodes veoticalis

Penmotis pulvenalis:

8 Pionea forficalis

9 Orobena extimalis

10 Orobena stramnalı:

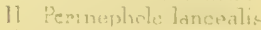

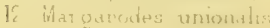




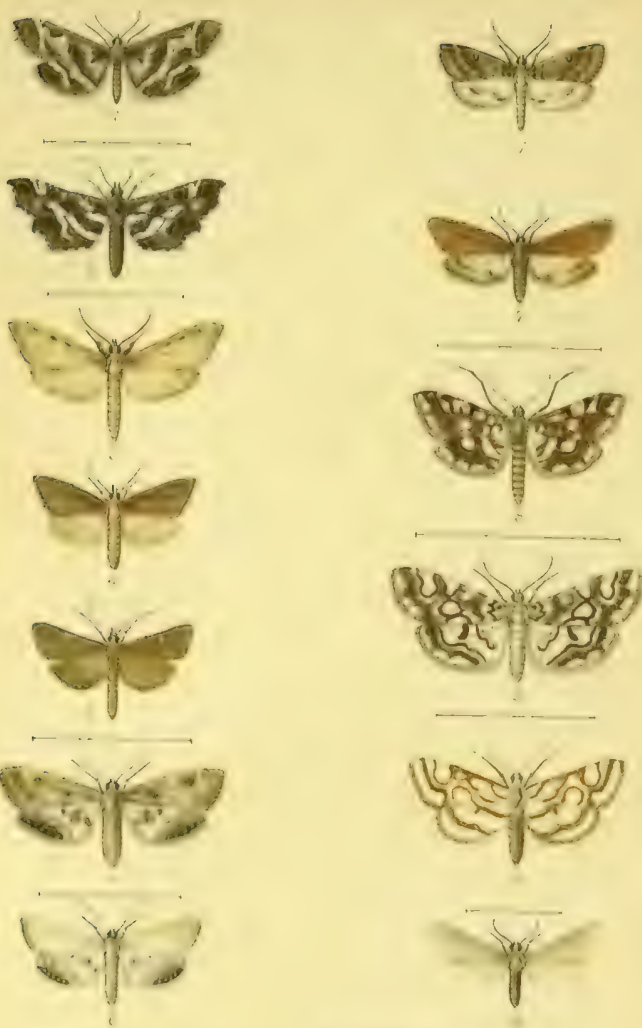

1 . semma Jiterata

2 Diasemia rambursatic:

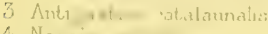

4. Nasci.

ysta lemnata.j. 7. Panaponys stratrotala.0.8 o hydrocampa nymplisiata is Hydeocampa staj 


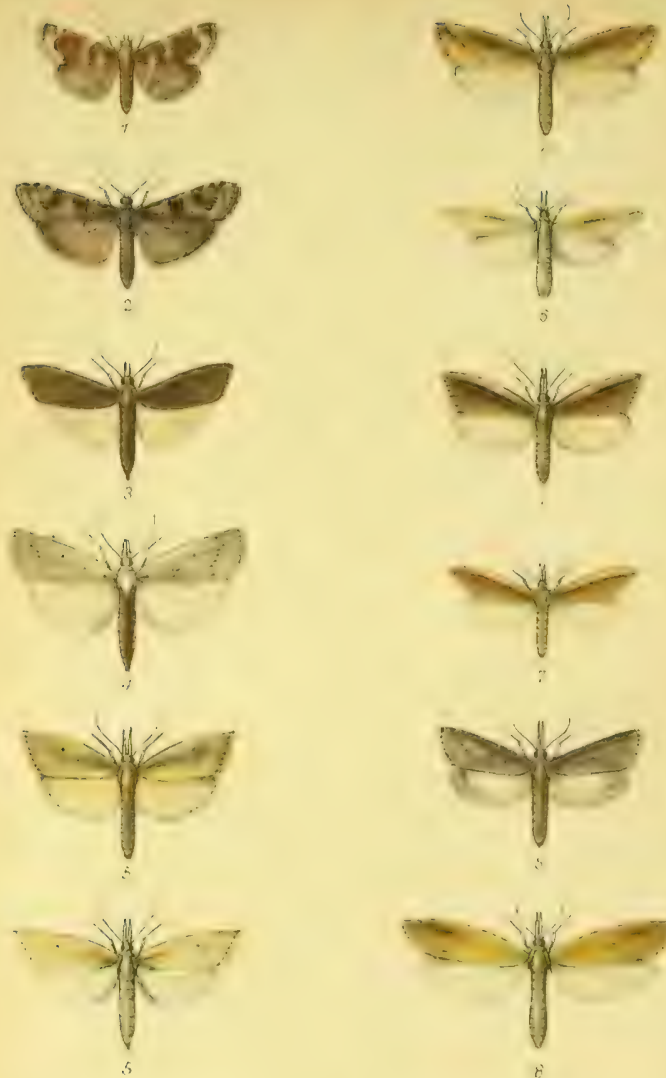

1. Byralis henigratis

2 Nomophila noctuella 3 Chilo cicatricellus. 4. Calomotropha paludella. WRirk: Jith
$\Rightarrow$ Chilo phrocinittelus d.o

- Schoenobius forficellus. d.o.

if Schoenobius mucronellus ds

$\therefore$ Schoenobius gionantellus.ô. Hanhart ums 


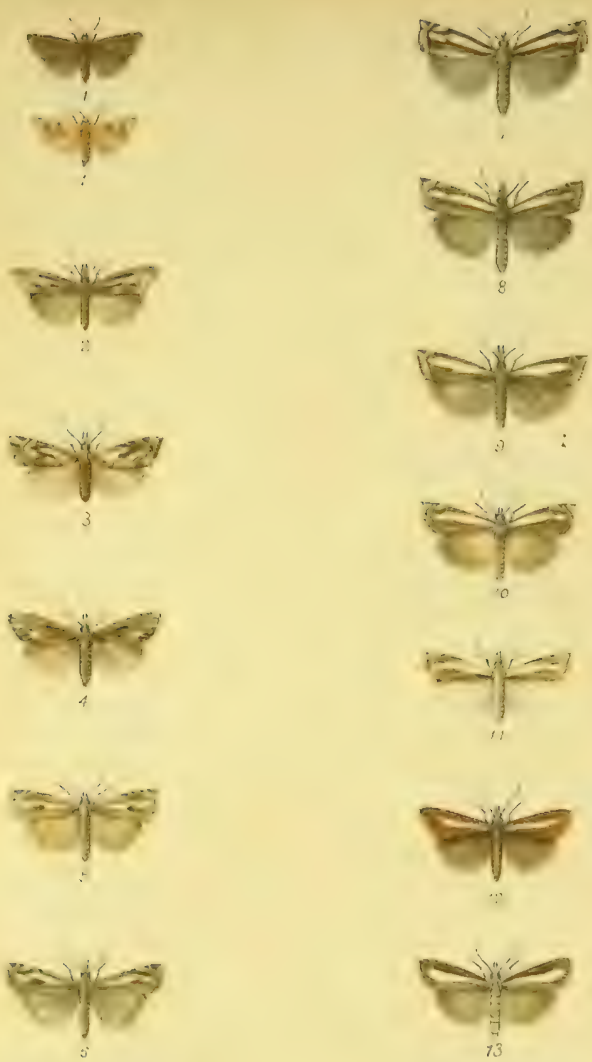

1 Platytes ceruse]lus. do

2. Cramtrus atpinellus.

3. C: falsollus.

4. C: verellus.

5. C: pratellus.

6. C: dumetellus.

13. C: margartellus

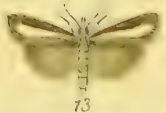

$7 \mathrm{C}$ emcellus.

8 C sylvellus.

9. C hamellus

10 C pascuetlus.

11. C uliginosellus

12. C furcatellus. 


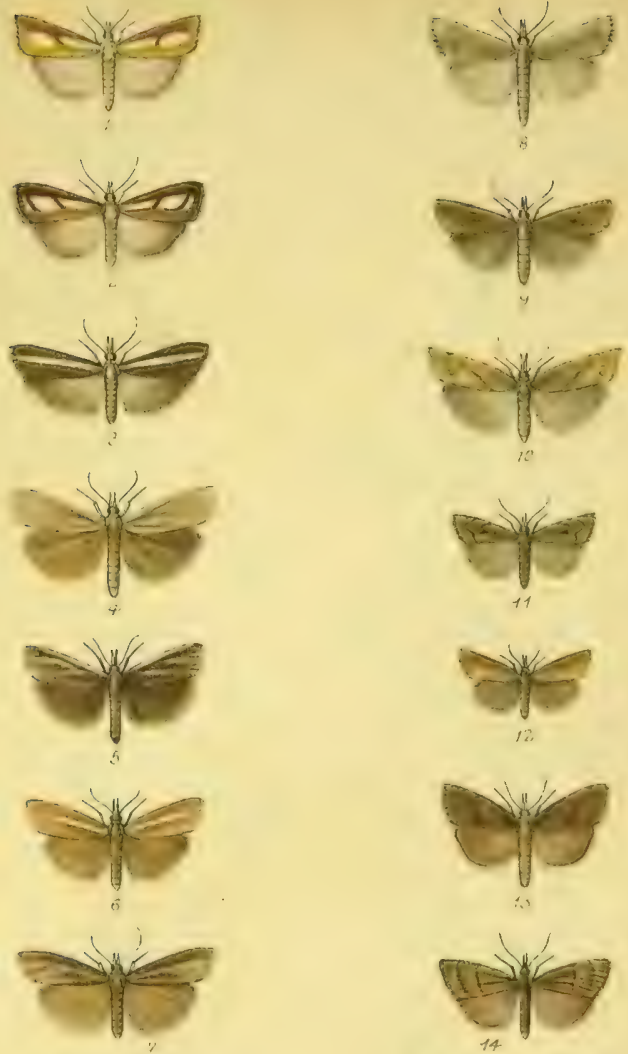

1. Unambus pinellus.

2. 6) myycilins

: g: iatistmun:

- ¿. perleilus

5. C: vor wasmotonellus

o. C: selasellus

7. C: pratollus.

(1) fascelinellus

- inquiratellus.

L : contominellus.

i) serviculors

I? () cutmellas.

$\because$, chrysonuchellus

14. i" craterellus 


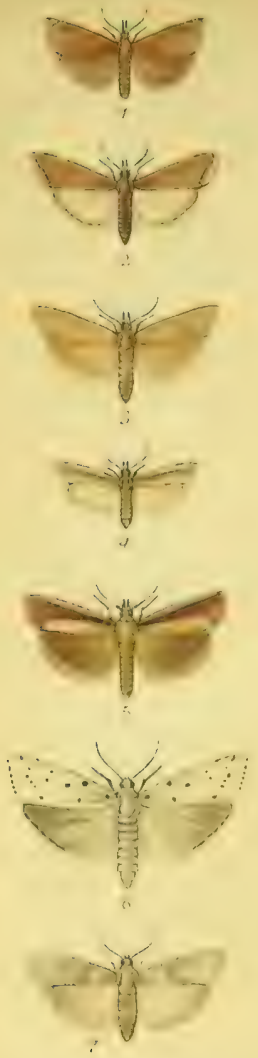

L'Trimbin: Thorberillun.: - nomence weller 3. Amerathia [nt..3]::

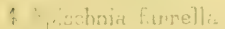
5. Ilithyia azminubolla 4. Wyelentulin mibsun i Tricionu: Fnyerolla
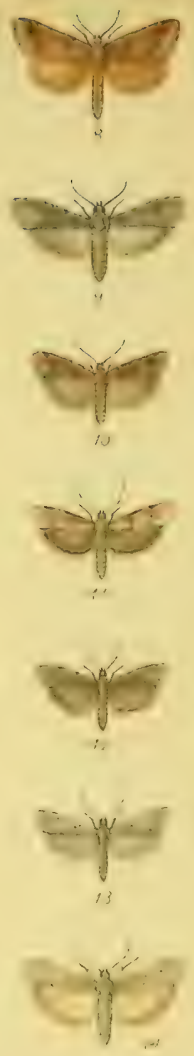

Myeloic cimsigenella. Myelois cenatonide Nrctognates achatinnl! a lomxiosoma sinuelia - Komorosomi zimbelle.

$\therefore$ : Tomoeorma saktcols

- ilonusersomar remu will. 

Britisin Pyrahdes \&ce
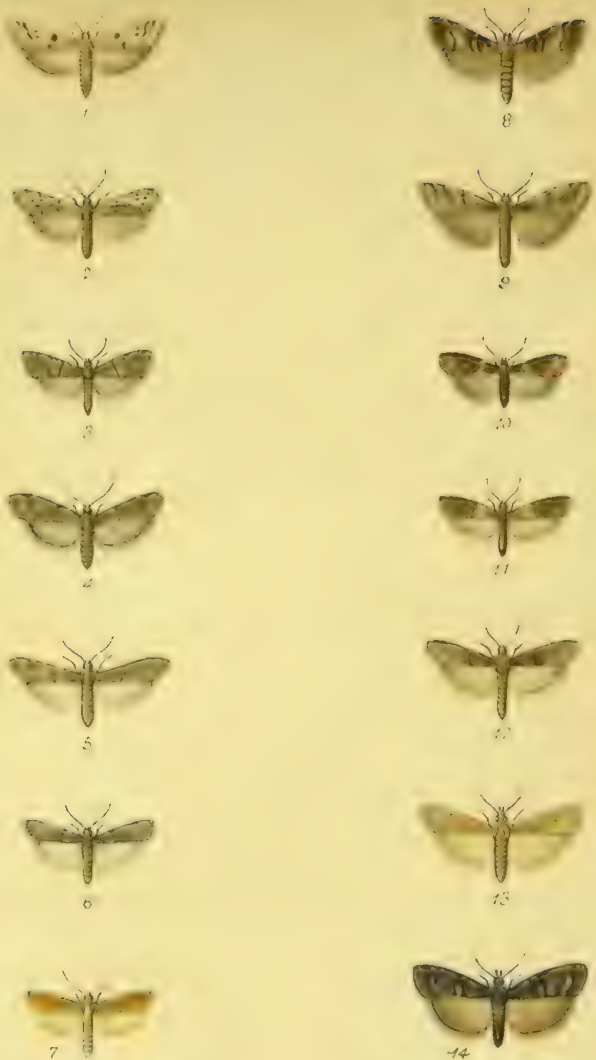

1. Homceosuma binævella..

2. Homoeosoma senecionis

3. En hestia elutella.

4. Ephostia passulella

5. Ephestin picella

6. Ephestra ficulella

7. Ephestia semirufa.

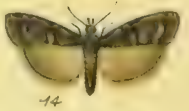

8. Euzophera punguis

9. Euzophera cinerosella.

10. Cryptoblabes bistriga

11. Plodia interpunctella

12. Alispa angustella.

13. Gymnancyla camella

14. Phycrs betrila 

Ärituel Pyratide: \& \&
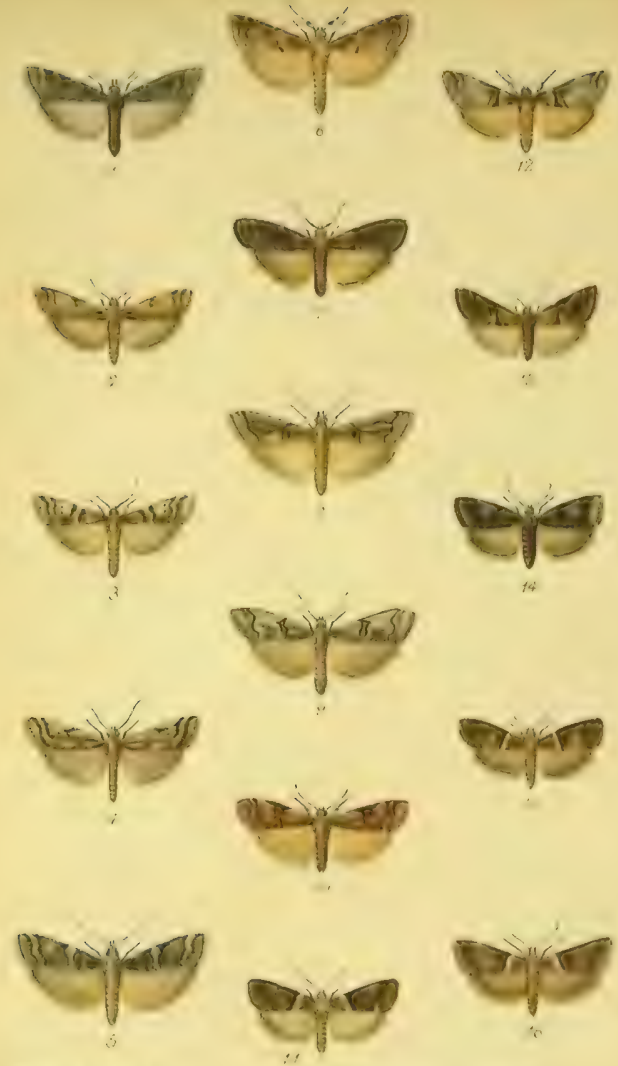

$11 . v_{1}^{2}: ;:$ : : *

2. Phycis do matella

3. Phycis s menatelli

+ Phycis omiatells

; Dioryctria abietelli

6. Nephopteryox spisisicells

7. Nephopterys rheneila

8 Nephopteryx csemstelld WRarhavs bh.
Permulia : mbella thodophaé. rmas Rhoriophwa :onsomplia Rhodophasa aivenella Reodophusa inanunomea

1.. Rhodophada suavella

- , p mamiderla

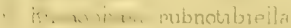




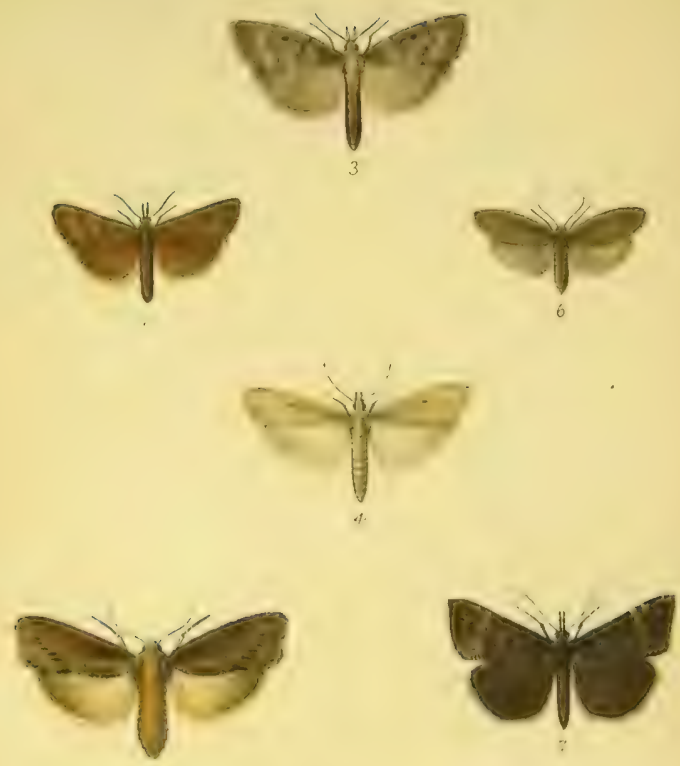

$\therefore$

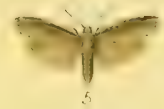

1. Oncocera ahenella.

2. Galleria mellonella.

3. Aphomia sociellir.
5. Melissohlaptes cephatonica

6. Ochroca grisclla

7. Hypena obsitalis 

Fontun Fy liad $\because 4 a$
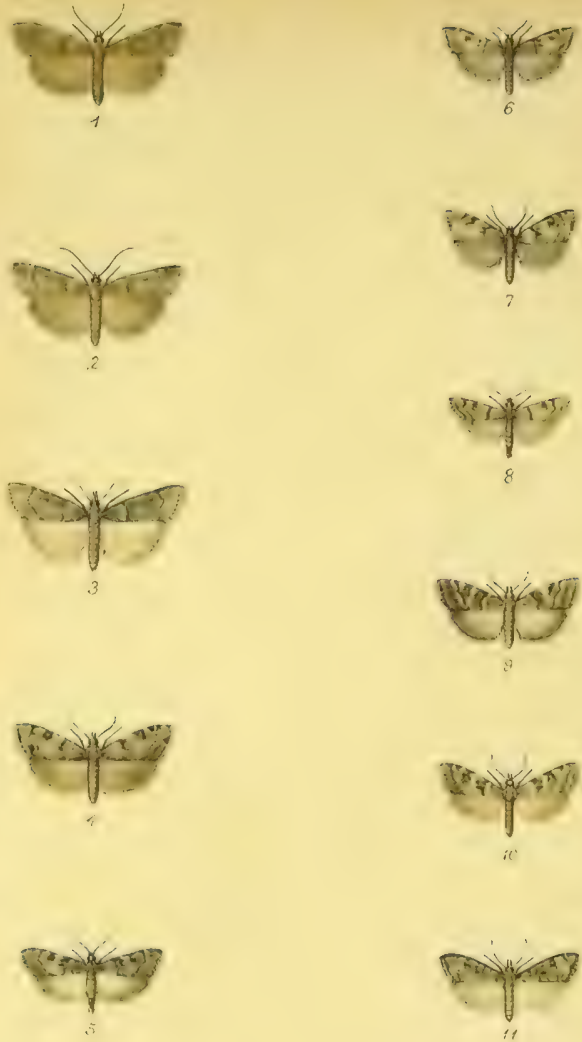

1 Scoparia cembroo

2 var: zellem.

3. var: scotica.

4. Scoparia basistriģalis.

5 Scoparia ambiguahs.

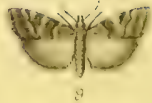

o var alomales

7 Scoparia conspicualis.

B Scoparia ulmolla

9 Scopama aubitalis

13 var mgrabella 


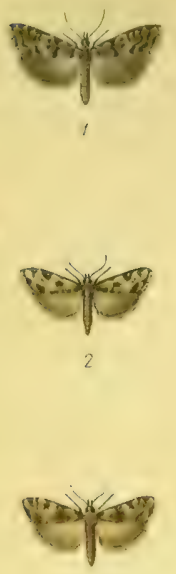

3

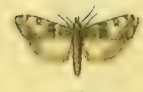

it

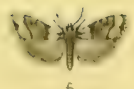

1. Scoparia munana.

2. Scoparia resinea.

3. Scoparia mencurella.

4. Scoparia creategella
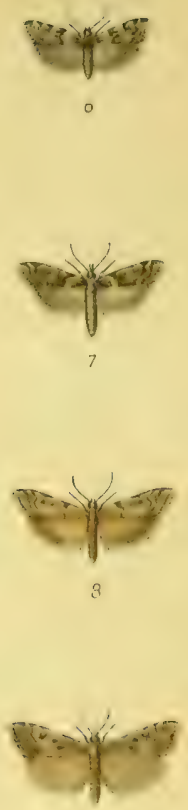

,

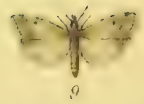

6. Scopama lineolca.

7. Scoparia angustea.

8. Scoparia alpina. ơ

o.se para pulh Scoparia phæolenca. 

British Byratides kc.
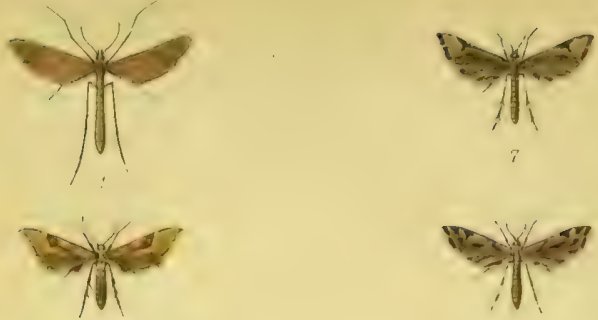

is

b
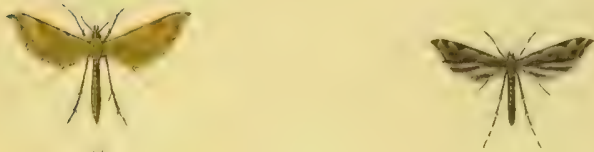

$+$

!
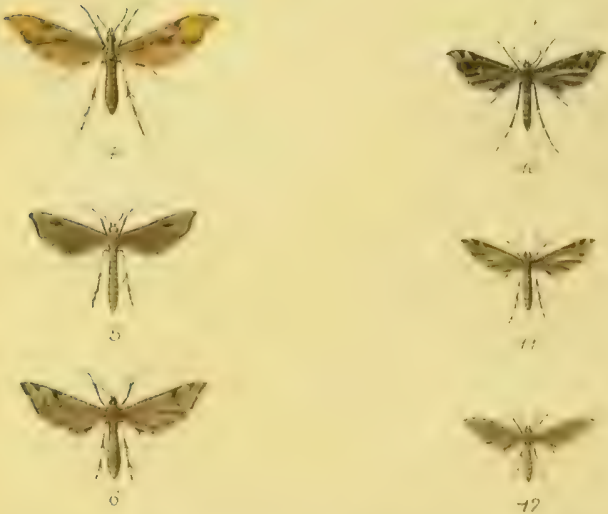

1. Agdistis benetii.

7. Platyptilia zettenstcalt

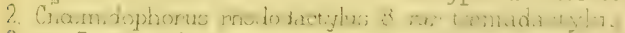

3. $\operatorname{var}$ bertrami.

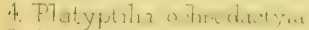

5. Platyptilia isodactylus.

6. Platyptina gonodactyla.

9. Amblyptilia acanthodactyia

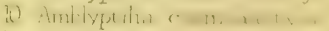

11. Oxyptilus distans

12. var lactus 


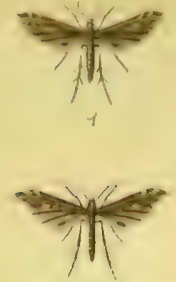

2

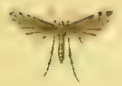

3
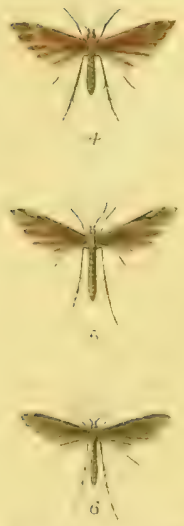

1 ixy!the inline 11.x

2. Oxyptilus teucrii.

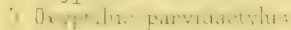

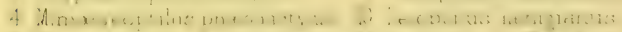

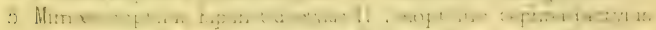

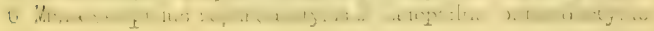
WRukies Jik
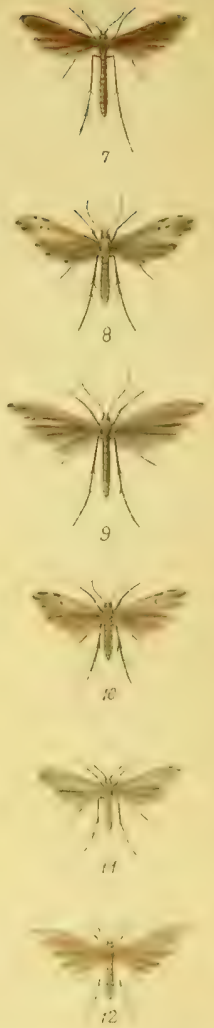

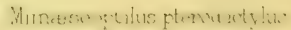

8. Edematophorus hithodactylus.

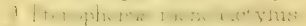

Hasbatt amp. 


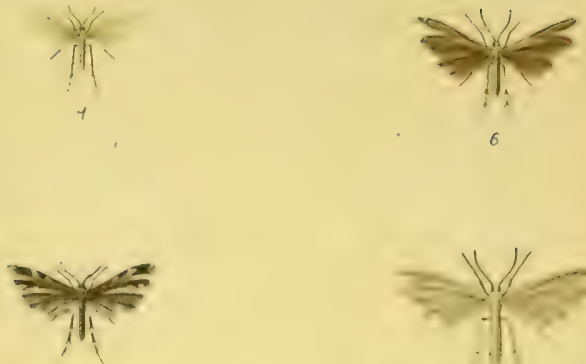

2
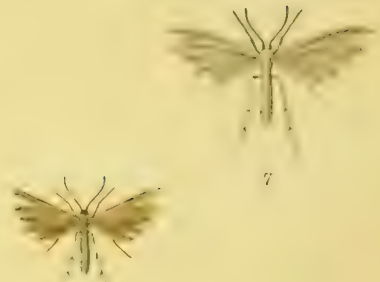

i

\section{5}

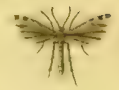

8

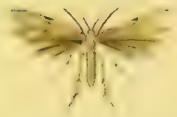

4

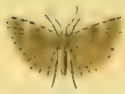

8

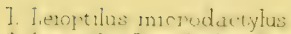

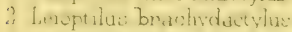

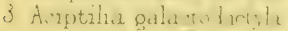

- Acpotia pilodectil.

5. Acrptilia balio dactyla.

6 Acsptsia tetraiactyla

7 Aciptila pentadiactyla

18 Ariptilad paludum

A Aluritis hexadactyla 

17 if 
